\title{
Allocation to Anchor Investors, Underpricing, and the After- market Performance of IPOs
}

Seth, Rama; Vishwanatha, S. R.; Prasad, Durga

\author{
Document Version \\ Published in: \\ Financial Management \\ DOI: \\ 10.1111/fima.12210 \\ Publication date: \\ 2019 \\ License \\ Unspecified
}

Accepted author manuscript

Citation for published version (APA):

Seth, R., Vishwanatha, S. R., \& Prasad, D. (2019). Allocation to Anchor Investors, Underpricing, and the Aftermarket Performance of IPOs. Financial Management, 48(1), 159-186. https://doi.org/10.1111/fima.12210

Link to publication in CBS Research Portal

\section{General rights}

Copyright and moral rights for the publications made accessible in the public portal are retained by the authors and/or other copyright owners and it is a condition of accessing publications that users recognise and abide by the legal requirements associated with these rights.

\section{Take down policy}

If you believe that this document breaches copyright please contact us (research.lib@cbs.dk) providing details, and we will remove access to the work immediately and investigate your claim.

Download date: 26. Apr. 2023

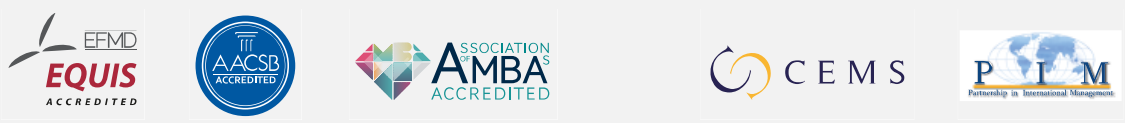




\section{Allocation to Anchor Investors, Underpricing, and the After- market Performance of IPOS}

\section{Rama Seth, S. R. Vishwanatha, and Durga Prasad}

Journal article (Accepted manuscript*)

\section{Please cite this article as:}

Seth, R., Vishwanatha, S. R., \& Prasad, D. (2019). Allocation to Anchor Investors, Underpricing, and the Aftermarket Performance of IPOs. Financial Management, 48(1), 159-186. https://doi.org/10.11l1/fima.12210

This is the peer reviewed version of the article, which has been published in final form at DOI:

https://doi.org/10.1111/fima.12210

This article may be used for non-commercial purposes in accordance with

Wiley Terms and Conditions for Self-Archiving

* This version of the article has been accepted for publication and undergone full peer review but has not been through the copyediting, typesetting, pagination and proofreading process, which may lead to differences between this version and the publisher's final version AKA Version of Record. 


\title{
Allocation to Anchor Investors, Underpricing and the After Market Performance of IPOs
}

\begin{abstract}
We study bidding by anchor investors in a two-stage IPO process. We document a negative, causal relation between allocation to anchor investors and underpricing. We find that anchor investors are likely to invest in hard-to-place offerings suffering from valuation uncertainty. We document a positive relationship between allocation to reputed anchor investors and returns up to lock-up expiration. Our evidence provides support to information revelation and targeting specific investors' theories of book building. We also find that anchor backed IPOs earn superior returns mainly through monitoring. Who bids in an IPO seems to matter just as particular types of bids do.
\end{abstract}

Keywords: Initial Public Offering, Equity Issue, Going Public, Book Building, Anchor Investors JEL Classification: G15, G24, G32 
IPO activity and pricing have been the subject of scholarly debate for decades (Ritter and Welch, 2002). A major difficulty in IPO research is the lack of direct evidence on IPO allocations because books are opaque. We bridge this gap by using a legal experiment in India ${ }^{1}$. On July 9 , 2009, the Securities Exchange Board of India, the stock market regulator, allowed a two-stage IPO process in which qualified institutional investors were allowed to act as anchor investors (or lead investors) in initial public offerings. Under the law, anchor investors are allotted shares on a discretionary basis and the price at which allocation is made is disclosed by the lead investment bank one day before the opening of the offer to the public ${ }^{2}$. If the price fixed for public issue through the book building process is higher than the price at which allocation is made to anchor investors, the additional amount is to be paid by anchor investors. However, if the price fixed for public issue is lower than the price at which the allocation was made to anchor investors, the difference would not be payable to anchor investors. These investors face a short lock-up period of 30 days from the date of allotment. Thus, the Indian IPO process is a sequential hybrid mechanism in which anchor investors lead the price setting process ${ }^{3}$.

\footnotetext{
${ }^{1}$ We have recently become aware of a working paper on anchor investors by Bubna and Prabhala (2013). Our results are different from theirs because of differences in variable construction, sampling, and econometric methodology. 2

In other countries, institutional investors are allocated shares along with other classes of investors such as retail investors once the book is closed.

${ }^{3}$ The Indian experiment is consistent with Jagannathan and Sherman (2005) who suggest modifying the book building method in order to retain its advantages (vis-à-vis auctions) while at the same time making it transparent and encouraging retail participation. The National Stock Exchange and Bombay Stock Exchange have nationwide trading network and conduct online IPOs. The process allows investors to observe bids made by different classes of investors. This makes the book building process transparent.
} 
This paper seeks to answer several important questions: How does the involvement of anchor investors affect underpricing? How do anchor investors decide in which issues to request allocations? Are anchor investors given disproportionate allocations in substantially underpriced IPOs? Do they have a destabilizing impact on stock prices around the lock-up expiration date? Do anchor-backed IPOs have higher risk-adjusted returns than non-anchor IPOs in the long run? Although our analysis focuses on India, our research design is equally applicable to other countries with similar IPO processes (e.g. Hong Kong).

This topic is of more than academic interest. Regulators have been concerned about the potential conflict of interest between investment banks and investors for many years. Investment banks have the discretion to allot shares in an IPO. The literature has shown that investment banks allot shares in hot IPOs (i.e. highly underpriced IPOs) to institutional investors in return for assured investment in IPOs (e.g. Loughran and Ritter, 2002, Bubna and Prabhala, 2011). Our setting allows us to examine if this is the case. By studying the Indian experiment, a larger issue we address is whether regulators should consider moving to a two-stage IPO mechanism and if they do, how the process would affect issuers and investors.

Our analysis uses data on 282 Indian IPOs from 2007 to the first quarter of 2013 including 52 IPOs with anchor investor participation. The sample consists of IPOs from 2007 although the legislation came into effect in 2009 for two reasons. First, we undertake difference-in-difference estimation throughout the paper. It is necessary to define a time window around the introduction of the legislation. Second, one firm had voluntarily enlisted anchor investors in 2007. Further, we carry out robustness checks by including IPOs till March 2016. We stop at March 2016 because annual financial data were available till March 2016 when we collected the additional data.55 IPOs were made during 2013-2016 out of which 19 firms were anchor backed. 
We exploit the legal reform to investigate whether the introduction of anchor investors lowers underpricing and valuation uncertainty and generates higher risk-adjusted returns in the long run. We contribute to the literature in several ways. The anchor investor scheme might be beneficial to retail investors. On the positive side, institutional investors with large blocks of shares would have economies of scale and the information processing ability to actively shape a firm's management, suggesting a positive impact on firm value (Shleifer and Vishny, 1986). Mello and Parsons (1998) point out that a two-part issuing strategy may be more efficient, with the IPO aimed at atomistic investors and a subsequent private placement aimed at institutional investors who are blockholders. On the negative side, Mello and Parsons argue that selling a large block first (as is the case with the Indian system) may avoid the free rider problem (Grossman and Hart, 1980) and the winner's curse problem faced by small investors (Rock, 1986) but by assuring active investors a large block of shares, it becomes impossible to extract the maximum price from most types of active investors. Because large investors with low valuations are assured shares, issuers would have no mechanism to force a better price from those with higher valuations. As a result, conducting sequential sales assures them an even greater discount than the optimal. Thus, the Indian setting allows us to not only observe allocations and the price at which institutional investors receive shares but also empirically test the prediction of Mello and Parsons (1998) and examine how such an allocation impacts underpricing.

Lowry, Officer and Schwert (2010) raise questions about the efficacy of traditional firm commitment offerings because of underwriters' inability to value firms facing valuation uncertainty. They point out that auctions could be beneficial for such firms. It is likely that firms facing asymmetric information may enlist anchor investors to credibly convey firm quality as well as achieve price discovery. Consistent with this prediction we find that anchor investors are more 
likely to invest in smaller firms facing valuation uncertainty and that these IPOs are less likely to be priced at the upper end of the price band. We find that these firms are less profitable and take longer to go public. That is, these are hard-to-place offerings. Further, anchor investors are allotted a larger fraction of shares in smaller IPOs and in smaller firms. This is consistent with prior research, which shows that the auction regime is less costly for small issuers; (Kutsuna and Smith, 2004) and Binay, Gatchev and Pirinsky (2007) find that relationship participation is higher in IPOs of smaller firms.

In $92 \%$ of anchor-backed IPOs, the final offer price is set equal to the price at which anchor investors were allocated shares. In $8 \%$ of IPOs, the final offer price deviates from the price at which anchor investors were allocated shares by $4 \%$. Thus, the Indian experiment encourages price revelation. Our main result is that, after controlling for heterogeneity, anchor investors reduce pricing errors because of which IPOs backed by anchor investors are less underpriced. These investors are less likely to be allotted shares in hot (highly underpriced) IPOs. On the other hand, they cause the underpricing to fall. We undertake a number of robustness checks throughout the paper. Our findings are generally robust to alternate econometric methodologies such as multivariate regressions, propensity score matching and difference-in-difference estimation.

Anchor backed IPOs fail to generate better returns than non-anchor IPOs after adjusting for Fama-French risk factors. However, we find that anchor-backed IPOs earn superior returns through monitoring when anchor investors invest along with institutional investors known to be active monitors. Anchor backed firms generate a positive alpha of $1.25 \%$ per month (or $15 \%$ per annum) in both three and four factor specifications. Collectively, our findings provide evidence to support "information revelation" and "targeting particular investors" theories of book building and the monitoring role of institutional investors. 


\section{Theory and Related Research}

Three main explanations have been advanced to explain IPO allocations and pricing. These are information revelation, conflicts of interest, and targeting particular investors theories of book building (Jenkinson and Jones, 2009). Cornelli and Goldreich (2001, 2003) provide evidence to support the information revelation theory. They find that allocations are related to certain types of bids that are considered to be more informative. Jenkinson and Jones (2004) find that allocation is influenced by the (perceived) investment horizon of the investor. That is, long term investors are more likely to be allocated shares. These papers examine allocation in European IPOs managed by particular investment banks. Using a dataset of U.S offerings, Aggarwal et al. (2002) document a positive relation between institutional allocation and underpricing. They provide evidence to support the book building theory of IPO underpricing. Using an Indian dataset, Bubna and Prabhala (2011) find that allocations are related to bidder identity rather than the bid itself. They find that domestic mutual funds and foreign institutional investors are favored more than other types of investors such as banks and insurance companies. Binay et al. (2007) find that underwriters favor regular investors more than infrequent investors in underpriced issues. They find that relationship participation is more important in IPOs of less liquid firms and those underwritten by less reputed underwriters. Bids by anchor investors are useful in pricing an IPO due to information revelation. While other classes of investors such as venture capitalists who invest before the IPOs reveal valuation benchmarks, such valuations are not useful in pricing an IPO because VCs, for example, invest several months or years before the IPO. Their valuations would be stale. As pointed out in the previous section, in $92 \%$ of IPOs the offer price converges to the price paid by anchor investors. Further, anchor investors reduce valuation uncertainty (measured by the width of the price band) and valuation errors (absolute underpricing). Issuing 
firms may value more accurate pricing because of better investment choices that arise as a result of more accurate pricing (Benveniste, Busaba, and Wilhelm, 1997; Subrahmanyam and Titman, 1999)

A few other papers have focused on agency problems between investment banks and issuing firms. Degeorge, Derrien and Womack (2007) find that book-built issues were more likely to be followed and positively recommended by the lead underwriters' and non-underwriters' analysts as a way of currying favor with the IPO underwriter for allocations of future deals. Likewise, Ritter and Zhang (2007) find that IPO underwriters favor affiliated mutual funds. Since the securities law in India prohibits underwriters from appointing related investors as anchors, agency conflicts are less likely. Consequently, we focus on price revelation and targeting specific investors' theories of book building.

Both book building and agency theories predict that certain types of investors would be favored in allocations. We examine if underwriters favor certain groups of investors. The anchor investors' league table is headed by top global fund management companies such as Morgan Stanley, Credit Suisse, Citigroup Global Markets, Deutsche Securities, and T Rowe Price. At the same time, relatively less well known, smaller companies such as Ironwood Investment Holdings and Indea Capital too act as anchor investors. We posit that bids by investors who commit greater amounts of capital and those who act as repeat purchasers to be more informative because they would have the bargaining power with underwriters. Further, they may have private information unavailable to other investors. We measure the reputation of an anchor investor by its market share just as the reputation of an underwriter is measured by its market share ${ }^{4}$. We set the reputation

\footnotetext{
${ }^{4}$ Market share is simply the ratio of capital committed by an anchor investor in a year across all IPOs and the total capital committed by all anchor investors to all IPOs in a year. We posit that issuers would approach only those anchor
} 
score equal to the market share. By design, the total of reputation scores of all anchor investors equals 100 . These reputation scores are then translated into an IPO-reputation score by summing up the scores of each anchor investor backing the IPO. All IPOs with reputation scores above the median are classified as backed by reputed anchors. It is worth pointing out that our reputation measure is not necessarily related to the size of the investor. It measures the level and frequency of investment from an investor. This measurement is similar to the participation measure used by Binay et al. (2007). We hypothesize that these investors would be favored by issuers because they help firms in raising the necessary capital.

Does allocation to anchor investor reduce underpricing? The literature provides conflicting predictions. In book building theories, investment banks and issuers engage in information acquisition and underpricing is a way to reward investors for truthfully revealing information during the road show. The relationship with investors helps firms by reducing underpricing. Agency explanations argue that underwriters favor regular investors in highly underpriced issues in exchange for other benefits from these investors (e.g. commission from trades executed by these investors on the listing day). That is, anchor backed IPOs ought to be more highly underpriced. Another strand of the literature shows that firms characterized by higher information asymmetry will be more underpriced (Beatty and Ritter, 1986 and Michaely and Shaw, 1994). Since anchor backed firms have higher information asymmetry, we would expect them to be more highly underpriced. On the other hand, since informed anchor investors aid price discovery, bids by other groups of investors and after market prices should be in line with the prices at which anchor investors were allocated shares.

\footnotetext{
investors whose investment sends a positive signal to other investors. Thus, the market share as defined above is a measure of reputation.
} 
Contrast this certification hypothesis with the alternative view based on "market power": anchor- backed IPOs are priced higher and further away from intrinsic value than non-anchorbacked IPOs (Chemmanur and Krishnan, 2012). The market power hypothesis posits that the role of anchor investors is to obtain the highest possible valuation for the IPOs that they back rather than to price the equity close to intrinsic value. This market power view has little merit in our context because anchor investors would not pay an offer price that would be in excess of the intrinsic value.

We posit that AI-backing lowers valuation uncertainty, which allows the issuer to set the offer price closer to the intrinsic value of the new issue (i.e., the first day market price). Thus, anchor backing lowers underpricing. An important lesson from the Indian experiment is that transparency in the IPO process might act as a self-regulatory mechanism in the sense that reputational concerns and legal action would deter investment banks from enriching preferred customers at the expense of other investors. The rest of the paper is organized as follows. In section II we describe the institutional setting, data and sample. In Section III we present empirical results. Section IV concludes.

\section{Institutional Setting, Data and Sample}

In this section, we describe the institutional setting, data and sample characteristics in detail.

\section{A. Institutional Setting}

The book building process in India is similar to that in the U.S.A and other developed markets. In India, each IPO is offered to three categories of investors: retail, non-institutional and 
qualified institutional buyers (QIB) or institutional investors ${ }^{5}$. The Indian securities law prescribes that (a) not less than $30 \%$ of the net offer be allotted to retail individual investors; (b) not less than $10 \%$ of the net offer be allotted to non-institutional investors i.e. investors other than retail individual investors and Qualified Institutional Buyers; and (c) not more than 60\% of the net offer be allotted to Qualified Institutional Buyers. If QIBs apply for exactly the same number of shares ear marked for them, the offer would have a subscription of 1x in the QIB category. Thus, a QIB subscription of 10x implies an oversubscription of 9x in the QIB category.

The Securities \& Exchange Board of India allowed qualified institutional investors to act as anchor (lead) investors in initial public offerings in order to boost investor confidence in IPOs $^{6}$.This legislation came into effect on July 9, 2009. Earlier laws required that pre-IPO placement of shares to other investors such as hedge funds and private equity funds be locked-up for one year, which prohibited investors from exiting. Further, issuers were compelled to issue shares at a discount to compensate investors for illiquidity.

Under the legislation, a company can carve out a maximum of thirty percent of the QIB section and offer it to anchor investors. The minimum application size for each anchor investor is INR 100 million. An anchor investor would apply for shares like a regular investor at the price it deems fit. The offer to these investors opens and closes one day before the offer opens to other categories of investors. Allocation to anchor investors are made on a discretionary basis subject to minimum number of two investors for allocation of up to INR.2.5 b and five investors for

\footnotetext{
${ }^{5}$ Qualified institutional investors are institutional investors who are generally perceived to possess expertise and the financial strength to evaluate and invest in the capital markets and registered with the Securities Exchange Board of India. There are around 300 QIBs in India.

${ }^{6}$ The 2007 crisis had eroded investor confidence in stock markets.
} 
allocation of more than INR.2.5 b. The number of shares allocated to anchor investors and the price at which the allocation is made are disclosed by the investment bank before the opening of the issue. These investors face a lock-in period of 30 days (on the shares allotted to them) from the date of allotment. The law prohibits entities related to the lead manager or founders of the company from acting as anchor investors. Typical anchor investors are public financial institutions, commercial banks, mutual funds, foreign institutional investors, multilateral and bilateral institutions, venture capital funds, insurance companies, provident funds and pension funds.

\section{B. Data Sources and Variable Description}

Our sample includes 282 IPOs that were issued between January 1, 2007 and March 31, $2013^{7}$, out of which 52 were backed by anchor investors. Sample firm and offer characteristics, including the data on anchor investors, are taken from the Prime IPO database, the Centre for Monitoring Indian Economy's Prowess Database, and company websites. We obtained stock price and index data from the websites of Bombay Stock Exchange and National Stock Exchange of India, and supplemented these with the information available on websites dedicated to IPOs (e.g. chittorgarh.com). Company and industry Price/Earnings multiple were obtained from IPO prospectuses. The allotment date for each IPO and recommendations from Business Line were hand collected from the websites of respective companies and Business Line.

\section{B.1. Variable Construction}

Appendix A provides a summary of the key variables used in our analysis and the data sources. We briefly discuss some of the important variables here.

\footnotetext{
${ }^{7}$ We began collecting data in April 2013. We have performed robustness checks by including IPOs made till March 2016. We report results for important test variables such as underpricing.
} 
Underpricing: We measure underpricing as the percentage return from the offer price to the first day closing price on the Bombay Stock Exchange. This is the definition used in prior papers (see, for e.g. Clarke et al., 2016).

IPO Relative Valuation: Investment bankers set the issue price using industry multiples. We use IPO P/E over Industry P/E as a measure of under or over valuation. We manually collect this information from IPO prospectuses.

IPO Duration (or registration or waiting period): Time elapsed (in days) between the prospectus filing date and the offer date.

Width of the price band: ((Maximum Price-Minimum Price)/(Minimum Price $)) \times 100 \%$ Update: ((Offer price-midpoint of the filing range)/(midpoint of the filing range) $)$ x $100 \%$ Lead Manager Reputation: To measure the quality of the investment banker/underwriter we use Thomson One Banker rankings and supplement it with listings in Prime IPO database. The top ten investment banks (lead managers) in terms of market share are considered reputed; others are not. The rankings are updated annually ${ }^{8}$.

Subscription: We measure investor subscription in three categories i.e. retail, non-institutional and Qualified Institutional Buyer (QIBs).

\section{Descriptive Statistics}

Table I reports the summary statistics for our sample. In Panel A we report the intertemporal distribution of IPOs. Approximately 50\% of IPOs in our sample were made during 20092013 Q1. Panel B of Table I shows that a median anchor-backed IPO has 8 anchor investors with $16 \%$ of shares being allotted to them. Panel C of Table I compares the firm and offer characteristics of anchor-backed and non-anchor IPOs. Anchor-backed firms are less liquid (measured by

\footnotetext{
${ }^{8} \mathrm{We}$ do not have data on market share of investment banks because it is not available in India.
} 
cash/current liabilities), more highly leveraged (measured by Debt/Equity) and are more capital intensive (measured by depreciation/sales). On average, anchor backed IPOs take 148 days to go public whereas non-anchor IPOs take 214 days $^{9}$. The difference in IPO duration is significant at the $1 \%$ level. It is likely that the involvement of anchor investors solves information problems for issuers and reduces the IPO duration. These IPOs have lower subscription from retail investors. Anchor backed IPOs are oversubscribed 4.08 times whereas non-anchor IPOs are oversubscribed 8.2 times. Anchor backed IPOs have higher listing-day trading volumes and are less underpriced. On average, anchor backed IPOs produce listing day returns (underpricing) of 7.68\% whereas nonanchor IPOs produce returns of $19.58 \%$.

The differences in other firm-level variables such as firm age, firm size, profitability (Return on Assets), operating cash flows, and offer characteristics (such as net proceeds and offer price) are not statistically significant. However, the differences in operating cash flows and ROA are economically significant. Anchor-backed IPOs have abysmal cash flows close to zero whereas non-anchor IPOs have much better cash flows. They also have poor profitability compared to nonanchor IPOs. Anchor-backed IPOs are more likely to be moderately priced vis-à-vis industry peers. $33 \%$ of non-anchor IPOs are priced at a premium to industry peers (in terms of Price/Earnings multiple) whereas only $21 \%$ of anchor-backed IPOs are priced at a premium. A majority (67\%) of anchor-backed IPOs get an avoid recommendation from analysts at Business Line, a prominent business daily.

\section{Empirical Results}

\footnotetext{
${ }^{9}$ The going public process consists of a number of activities such as shareholder and board meetings, filing of relevant documents with the registrar of companies, appointment of investment bankers, due diligence by investment bankers, and filing of draft prospectus with the Securities Exchange Board of India.
} 
In this section, we discuss the main results of the paper. The discussion is divided into five subsections.

\section{A. Underpricing}

Allocation to anchor investors is made on a discretionary basis. If the price fixed for the public issue through book building process is higher than the price at which the allocation is made to anchor investors, the additional amount shall be paid by anchor investors. However, if the price fixed for public issue is lower than the price at which the allocation was made to anchor investors, the difference shall not be payable to the anchor investors. If potential investors know that showing a willingness to pay a higher price will result in a higher offer price because later potential investors can learn from the purchasing decisions of earlier investors leading to cascades ${ }^{10}$ (Welch, 1992) they should be offered either more allocations or underpricing to truthfully reveal information.

In this section, we examine whether allocations to anchor investors is related to underpricing after controlling for pre-market demand (subscription) ${ }^{11}$. If this is the case we can infer that investment by anchor investors contains private information not captured by pre-market demand. We estimate three Ordinary Least Squares models with underpricing as the dependent variable.

Initial Return (i.e. underpricing) $=\beta_{0}+\beta_{1}$ (anchor dummy or reputed anchor dummy or percent shares allotted to anchor investors $)+\beta_{2-8}($ control variables $)+$ Time Fixed Effects + Industry Fixed effects $+\varepsilon$

The variable of interest in the first regression in Table II is the anchor dummy. Following earlier papers by Beatty and Ritter (1986), Hanley (1993), Aggarwal et al. (2002), and Deb and

\footnotetext{
${ }^{10} \mathrm{As}$ pointed out earlier, in $92 \%$ of anchor-backed IPOs the final offer price is set equal to the price at which anchor investors were allocated shares.

${ }^{11}$ Measuring subscription automatically captures oversubscription in an IPO because oversubscription is just subscription minus 1 .
} 
Marisetty (2010) we control for Update, IPO proceeds, lead manager reputation, standard deviation of 90 day returns of Nifty index prior to the prospectus filing date, 90-day average return of the Nifty Index prior to the prospectus filing date, firm age and VC backing. Clarke, Khurshed, Pande and Singh (2016) find that underpricing in India is primarily driven by unmet demand of noninstitutional investor groups and document sequential learning by retail investors. Therefore, we control for subscription by institutional and retail investors. Finally, we include but do not report year and industry dummies. The anchor dummy has a negative coefficient and is statistically significant indicating that anchor backed IPOs are less underpriced ${ }^{12}$. This is consistent with the findings of other researchers who find that IPOs priced at the upper end of the price band are more underpriced ${ }^{13}$. It is also similar to results of Megginson and Weiss (1991) who find that certification by venture capitalists leads to lower underpricing. In the second regression we replace the anchor dummy with reputed anchor dummy. Reputed anchor investors have an insignificant impact on undepricing. Benveniste and Spindt (1989) argue that underwriters give greater allocations to institutions who truthfully reveal their favorable information. Jenkinson and Jones (2004) and Binay et al. (2007) find that repeat purchasers or long term investors are given preferential allocations in IPOs that are more highly underpriced. Since we define reputed anchor investors as those with the highest market share, these investors are necessarily repeat purchasers. Anecdotal evidence and our interviews with a few market intermediaries revealed that anchors are long-term investors. Our findings do not support the "targeting specific investors" theory of book building as far as first day returns (underpricing) are concerned. However, since anchor investors

\footnotetext{
${ }^{12}$ Our results in this section and the subsequent sections are different from Bubna and Prabhala (2013) because of differences in variable construction, sampling, and econometric methodology.

${ }^{13}$ We show that anchor backed IPOs are less likely to be priced at the upper end of the price band.
} 
face a 30-day lock-up period, first day returns are less relevant to them. As we show later, IPOs backed by reputed anchor investors produce substantial returns up to lock-up expiration. This finding is consistent with the theory.

In the third regression, we replace the anchor dummy with percent of shares allotted to anchor investors. The results are qualitatively similar to the first regression. The greater the allocation to anchor investors the lower is the underpricing.

Critics of book building point out that investment banks make disproportionately large allocations in highly underpriced issues to their favored clients and the market is rigged against the average investor. This practice, termed spinning, has been widely documented in the U.S (e.g. Liu and Ritter, 2010). To examine this issue, we estimate an ordered Logit model (Regression 4) in which the dependent variable is an ordinal variable whose value is set at 0 if underpricing (U) is $\leq 0,1$ if $0<U<20 \%, 2$ if $20<U<40 \%$, and 3 if $U>40 \%$. The independent variables are percent of shares allotted to anchor investors, update, natural log of IPO proceeds and lead manager reputation. Table II shows that anchor investors are less likely to be allotted more shares in highly underpriced issues and that update is more likely to be correlated with the level of underpricing. We also find that reputed anchor investors are given allotments in an equal number of underpriced and overpriced issues with allocations evenly spread over issues with different degrees of under and overpricing suggesting that spinning is not prevalent in our setting.

As a robustness check we run the underpricing regression by including IPOs made after 2013 until March 2016. The results are in column 5. Our results show that underpricing reduces by $6.4 \%$. A related result (unreported) is that pricing error reduces by $9.13 \%$ when anchor investors are involved. The reduction in pricing error results in tighter pricing of IPOs.

\section{A.1. Propensity Score Matching and Difference-in-Difference Estimation}


The lower underpricing of anchor backed IPOs may be a result of firm size rather than anchor investors. As an alternative to the regression approach, we use propensity score matching and difference-in-difference estimation to establish causality. We consider anchor backing as the treatment, anchor backed IPOs as treated units and non-anchor IPOs as untreated units. The outcome is the observed underpricing. The propensity score is estimated within a year-size category as a function of controls such as VC backing, demand from institutional and retail investors for the IPO, volatility of 90-day index returns prior to filing, average 90-day index return prior to filing, firm age, issue size and firm size. We employ a two-stage procedure to match scores. In the first stage, the probability of receiving anchor investment is estimated by a logistic regression in which the dependent variable is the anchor dummy, a binary variable and the covariates are the observed characteristics of the vector. In the second stage, the predicted probabilities from the first stage are used as propensity scores in order to match observations from the two groups. That is, anchor backed IPOs are matched with non-anchor IPOs ${ }^{14}$. We employ the nearest neighbor 1:2 matching with replacement. In the first step, we consider IPOs made during 2009-2013 because the legislation came into effect in 2009. The absolute percentage difference between the issue sizes had to be less than 0.3 to be a successful match. Thus, we calculate the difference as: $\{$ Absolute (Issue size of AI - Issue size of Non-AI) $\} * 100 /$ Issue size of Non-AI.

The average differences in underpricing between anchor-backed and non-anchor IPOs and the $t$ statistics are summarized in Table III. The average underpricing difference is $62.26 \%$, which is significant at the $1 \%$ level. This difference is greater than the raw difference in underpricing (11.9\%) reported in descriptive statistics. The same table also reports the difference in absolute underpricing. Underpricing falls by $55.19 \%$ due to the involvement of anchor investors. This result

\footnotetext{
${ }^{14} \mathrm{We}$ also verified that covariates are balanced across treatment and comparison groups.
} 
supports the idea that anchor backing lowers pricing errors. As a robustness check we repeat the analysis for all IPOs during 2007-2013. That is, we match anchor backed IPOs with non-anchor IPOs since 2007 . The results are qualitatively similar. Underpricing falls by $25.64 \%$ when anchor investors are involved. This result is significant at the $1 \%$ level.

In the next step, we perform a difference-in-difference estimation as a further robustness check. AI is our treatment. AI-backed IPOs constitute the treated sample, and NAI denote the untreated sample. Panel A of Table IV shows the notation we follow for exposition. Entries in the cells display mean underpricing (UP). We can observe UP12, UP21, and UP22 but not UP on AIbacked IPOs during the pre-AI period. We use PSM (Propensity Score Matching) to identify a subset of NAI IPOs from the pre-AI period that have similar observable firm characteristics as the AI-backed IPOs in the post-AI period. That is, we match (by PSM) NAI IPOs that have roughly the same probability of choosing AI had the AI mechanism existed during the pre-AI period. The DiD test we perform focuses on the statistical significance of the following difference-indifferences:

$\mathrm{DiD}=\{[\mathrm{UP} 12-\mathrm{UP} 11]-[\mathrm{UP} 22-\mathrm{UP} 21]\}$

This entire group of AI and matched NAI firms (from the pre-anchor era) forms the treated group. For DID analysis, we need a control group. Naturally, NAI firms form the control group. We have $81 \mathrm{NAI}$ firms in the pre-AI period and 119 NAI firms in the post-AI period. We match NAI firms in the pre-AI period with NAI firms in the post-AI period.

In order to match propensity scores, we use four methods: Nearest Neighbor (NN) matching with and without replacement, Nearest Neighbor Matching with replacement with caliper set equal to 0.21 , and Mahalanobis Matching $(M M)$ with replacement. 
We use the logit model to calculate propensity scores. Matching with and without replacement gives similar results. However, NN matching without replacement is preferable as it uses more data. We plot underpricing of anchor and non-anchor IPOs for the entire period in Panel B of Table IV. The graph shows that many IPOs (70 firms out of 119) were overpriced before the anchor program. This period coincides with the 2007-2008 global financial crisis. Indeed, the crisis might have prompted the regulator to initiate the anchor program to instill confidence in investors. Panel C of Table IV displays the mean underpricing before and after matching using alternate PSM procedures. Selecting a Caliper of 0.21 results is a good match. Consequently, we choose this procedure. We present the results of DiD in Panel D of Table $\mathrm{IV}^{15}$.Our analysis suggests that underpricing falls by more than 50\% due to anchor investors' involvement.

The regression equation is:

$\mathrm{UP}=\mathrm{b}_{0}+\mathrm{b}_{1}$ Date dummy $+\mathrm{b}_{2}$ Anchor Dummy $+\mathrm{b}_{3} \mathrm{DID}+\varepsilon$

The parameters are Date Dummy, which is a Dummy variable for IPO launched before/after 2009; an Anchor Dummy variable and DID, which is the product of Date Dummy and Anchor dummy. The DiD coefficient (-50.856) is significant at the $1 \%$ level. The result persists when we control for firm, IPO and market variables by including the controls used in underpricing regression. Our analysis suggests that anchor backed IPOs are less underpriced by $69.766 \%$.

\section{A.2. Potential Endogeneity}

Other researchers such as Aggarwal et al. (2002) and Binay et al. (2007) jointly estimate allocation to institutional investors and underpricing using two stage least squares and seemingly

\footnotetext{
${ }^{15} \mathrm{We}$ have displayed only the values of underpricing in order to conserve space. The complete DiD table with covariates and industry and time fixed effects is presented in Appendix B. The results show that underpricing falls by as much as $80 \%$ after controlling for covariates, industry and time.
} 
unrelated regressions to address potential endogeneity between institutional investment and underpricing. In the U.S context institutional investors do not face a lock-up period. They can realize listing day returns (i.e. underpricing) by flipping shares. Anchor investors, on the other hand, face a 30-day lock-up because of which initial returns are of no consequence to them. These investors realize their returns once the lock-up expires. Consequently, we examine the cumulative abnormal returns around the lock-up expiration date to check if anchor investors have a destabilizing impact on stock prices by selling off shares. The expiration date can be deduced from the allotment date (by adding 30 days to the allotment date). We collected the allotment dates from the company websites and supplemented it with information available on websites dedicated to Indian IPOs (such as www.chittorgarh.com) and the stock exchange websites. We find that the 3day, market-adjusted, cumulative abnormal return around lock up expiration date is $0.006 \%$, which is insignificant. As a result, we do not expect reverse causality in our context ${ }^{16}$.

\section{B. Why are anchor backed IPOs less underpriced?}

In order to understand the impact of allocation to anchor investors on underpricing, it is necessary to understand a) the characteristics of firms and IPOs that receive investment from these investors; b) how these IPOs are priced within the offer price range and whether anchor investors solve valuation uncertainty for the IPOs that are backed by them and c) if anchor backed IPOs are hard to place offerings. Each of these have different implication for underpricing.

\section{B.1. The Determinants of Anchor Investors' Investment}

\footnotetext{
${ }^{16}$ In our context update is weakly correlated and institutional subscription is negatively related with anchor investment while anchor investment is negatively correlated with underpricing. Consequently two stage estimation is inappropriate. In the US context update is positively related to institutional allocation, which in turn is positively related to underpricing. Since the lock-up expires 2-3 weeks after listing, calculating risk-adjusted returns is problematic due to paucity of data points. Hence we calculate market-adjusted returns.
} 
We investigate the determinants of anchor investors' participation in an IPO. Specifically, we examine if anchor investment is related to publicly available firm and offer characteristics as in Field and Lowry (2009) and Binay et al. (2007) because firm characteristics are related to underpricing. We include firm age, lead managers' reputation, venture capital backing, IPO proceeds, relative valuation of the $\mathrm{IPO}^{17}$, and business group affiliation status as independent variables. In addition, we consider firm variables such as total assets, profitability (ROA), leverage (Debt/Equity), Sales/Assets, Cash/Current Liabilities (a measure of liquidity) and a cash flow dummy that takes the value of 1 if the operating cash flow is negative. We include a cash flow dummy because univariate comparison in Table I shows that anchor backed IPOs have poor cash flows compared to non-anchor IPOs. Smaller firms suffer from asymmetric information because of which they may find anchor investment attractive. Smaller IPOs may face the adverse selection problem faced by retail investors (commonly referred to as the "winner's curse" (Rock, 1986). These IPOs find anchor investment desirable. It is likely that anchor investors are recruited by firms that are not yet profitable but have valuable growth options. We also include time and industry dummies (coefficients not reported) to account for heterogeneity and potentially omitted variables. Table $\mathrm{V}$ presents the results of logistic and ordinary least squares regressions. We estimate the following Logit models:

Prob (Anchor ${ }_{i t}$ or Reputed Anchor $\left.i t\right)=\phi[\gamma$ Firm Financials and IPO Characteristics + Industry Fixed Effects + Time Fixed Effects]

Where $\phi \gamma$ denotes the logit distribution function and the dependent variable is either an anchor dummy or a reputed anchor dummy. The dependent variable in the first regression is a

\footnotetext{
${ }^{17}$ Price/Earnings multiple implied by the mid-point of the price range of the IPO divided by the prevailing industry Price/Earnings multiple.
} 
dummy variable that takes the value of 1 if an IPO attracted investment from anchor investors (zero otherwise). Column 1 shows that anchor investors are less likely to invest in bigger IPOs. Smaller IPOs that suffer from adverse selection problem are less likely to attract investment from other investors (especially retail investors). Anchor investors perform the useful role of bridging the gap. They are also more likely to invest when an IPO is backed by venture capitalists.

The dependent variable in the second regression is a reputed anchor dummy. We measure the reputation of an anchor investor by converting market share into a numerical score. Thus, if Morgan Stanley Mauritius has a market share of $6.06 \%$, it would have a reputation score of $6.06^{18}$. The reputation score of an IPO is the sum of scores of all anchor investors investing in the IPO. IPOs are then ranked on the basis of reputation score and all IPOs with a score greater than the median are classified as backed by reputed anchor investors. There is a negative relation between ROA, a measure of firm profitability, and anchor investors' involvement. That is, anchor investors are less likely to invest in firms that are highly profitable. Firms that are not (yet) profitable would find an association with anchor investors particularly attractive in marketing their offering. These firms are not necessarily lead managed by the most reputed underwriters. Indeed, reputed underwriters might be unwilling to consider a business relationship with these and the presence of anchor investors may obviate the need for reputed underwriters.

In the third regression, we examine if the determinants of the presence of anchor investors are similar to the determinants of the extent of anchor investment. The dependent variable is the percentage of shares allotted to anchor investors. We estimate the following OLS model:

\footnotetext{
Percent shares allotted $=\beta_{0}+\beta_{1-12}($ firm and offer characteristics $)+$ Time Fixed Effects + Industry Fixed effects $+\varepsilon$

\footnotetext{
${ }^{18}$ This methodology is similar to the measurement of lead managers' reputation in the IPO literature.
} 
Table V shows that anchor investors are allotted a smaller fraction of shares in bigger IPOs and in bigger firms. Conversely, they are allotted a larger fraction of shares in smaller IPOs and in smaller firms. They are more likely to invest in VC backed IPOs. To summarize the results of this section, anchor investors perform the useful role of helping smaller firms raise equity capital. While prior empirical evidence on IPOs shows that smaller IPOs are more highly underpriced, in our context, anchor investors solve the winner's curse problem faced by such firms. Consequently, they are less underpriced.

\section{B.2. Do Anchor Investors Reduce Valuation Uncertainty?}

In this section, we discuss the impact of anchor investors' involvement in resolving valuation uncertainty and hence, underpricing. In order to examine the influence of pre-selling activities such as enlisting anchor investors on the IPO process, we regress width of the price band on anchor dummy and controls ${ }^{19}$. We estimate the following model:
Width of the Price Band $=\beta_{0}+\beta_{1}($ anchor dummy $)+\beta_{2-3}($ control variables $)+$ Time Fixed Effects + Industry Fixed effects $+\varepsilon$

The width of the price band, a proxy for IPO risk, measures the valuation uncertainty surrounding an IPO (Hanley, 1993). Underwriters are likely to set a wider price band when they need to retain flexibility in pricing the issue. Results in the previous section suggest that anchor investors are more likely invest in smaller IPOs that are riskier. These firms are also less profitable. Issuers may enlist anchor investors when there is uncertainty in pricing the issue. Anchor investors reduce valuation uncertainty by bidding one day before the IPO opens to other classes of investors.

\footnotetext{
${ }^{19}$ In India, the underwriter drafts a prospectus and undertakes a road show to meet potential investors and uses the information gathered during roadshows to set the price band. Consequently, the width of the price band is the dependent variable. In several other countries (e.g. the U.S) the underwriter sets the price band and then undertakes a roadshow.
} 
Although they resolve valuation uncertainty for all IPOs, those with wider price bands would benefit the most from recruiting anchor investors. While price discovery may not be the sole or the primary objective of underwriters, the two-stage IPO mechanism combines the benefits of price discovery without sacrificing any of the other services associated with traditional book building.

The variable of interest in the first two regressions is the anchor dummy. We control for IPO size, firm size, firm age, standard deviation of Nifty Index returns over 90 days prior to the prospectus filing date ${ }^{20}$, average return on Nifty index over 90 days prior to the prospectus filing date and other forms of certification such as lead manager reputation, venture capital backing, and group affiliation. When the stock market is volatile, underwriters would like to set a wider price band so that the price does not become unattractive should the market move in an adverse direction. Likewise, the higher the returns from the market, the lower is the valuation uncertainty in that investors would be willing to pay better valuations resulting in lower valuation uncertainty. Investors may take lead manager reputation or affiliation to an established business group or venture capital backing as proxy for (lower) risk.

In model 1, we deliberately do not include time and industry dummies. Table VI shows that anchor backed IPOs have narrow price bands, which implies that anchor-backed IPOs have lower valuation uncertainty. The coefficient of firm age is negative in line with the notion that younger firms that are more difficult to value have wider price bands. In model 2, we include time and industry dummies (coefficients not reported) to account for potential heterogeneity and omitted variables. Results show that anchor investors do not have a significant impact on the width of the price band. In regressions 3 and 4 we repeat the analysis with the reputed anchor dummy.

\footnotetext{
${ }^{20} \mathrm{Nifty}$ is the flagship index of the National Stock Exchange of India and is widely used by the investment community.
} 
The results are qualitatively similar. These results persist when we repeat the analysis by extending the sample period to 2016 .

As an alternative to the regression approach, we use propensity score matching methodology to establish causality. We consider anchor backing as the treatment, anchor backed IPOs as treated units and non-anchor IPOs as untreated units. The outcome is the observed width of the price band. We employ the nearest neighbor 1:2 matching with replacement. The results show that the width of the price band falls by $1.99 \%$. This supports the notion that anchor investors reduce valuation uncertainty. This result holds when we perform a difference-in-difference estimation. The width of the price band falls by $3.1 \%$ when anchor investors are involved. This reduction in valuation uncertainty results in lower underpricing.

\section{B.3. Are Anchor Backed IPOs hard to place offerings?}

The maximization-of-proceeds hypothesis suggests that anchor investors would enable issuers to get the best possible price by pricing the IPO at the upper end of the price band. This is consistent with Benveniste and Spindt (1989) who propose that proceeds maximizing investment banks should give priority to regular investors when allocating shares. We examine if this is the case when anchor investors are involved. The dependent variable in Regression 1 of Table VII is a dummy variable that takes the value of 1 if an IPO is priced at the upper end of the price band. We estimate the following Logit model:

Prob (IPO Priced High $\left.{ }_{i t}\right)=\phi[\gamma$ Firm Financials and IPO Characteristics + Industry Fixed Effects + Time Fixed Effects]

Where $\phi \gamma$ denotes the logit distribution function. We control for IPO proceeds, lead manager reputation, and percent change in the Nifty index between the prospectus filing date and the offer date. We introduce year and industry dummies as before. IPOs underwritten by reputed 
investment banks can perhaps price their offering at or near the upper end of the price band. When market changes negatively between the filing date and the offer date, underwriters may be wary of pricing the issue closer to the upper end of the price band. We find that anchor backed IPOs are less likely to be priced at the upper end of the price band. Thus, anchor backed IPOs are less underpriced $^{21}$. We also examine whether reputed anchor investors enable issuers in pricing the IPO at the upper end of the price band or above the midpoint of the price band. The results do not change. Our results confirm the prediction of Mello and Parsons (1998) that when institutional investors are assured of allocation before the IPO they would always bid low.

Univariate comparisons in Table I show that anchor-backed IPOs have statistically and economically shorter waiting period compared to non-anchor IPOs. Firms facing demand uncertainty or asymmetric information take longer to go public. This applies to firms in risky industries too. The presence of anchor investors may accelerate the process of raising capital on account of sequential learning by other market participants. Colaco and Hegde (undated) find that IPOs with shorter waiting periods exhibit lower underpricing. The dependent variable in regression 2 is IPO Duration (or registration or waiting period), which is defined as the time elapsed (in days) between the prospectus filing date and the offer date. Since the dependent variable is count data, we run a negative binomial regression, which allows for over dispersion in waiting period. We control for IPO proceeds, lead manager reputation, and percent change in Nifty index between the filing date and the offer date. We include year and industry dummies. We expect smaller IPOs (such as those backed by anchor investors that are riskier) to have longer waiting periods. Regression 2 shows that anchor backed IPOs have longer waiting period. This result is consistent

\footnotetext{
${ }^{21}$ Prior papers show that IPOs priced at the upper end of the price band are more highly underpriced.
} 
with the notion that anchor investors are likely to be enlisted in hard-to-place offerings ${ }^{22}$. This result persists when we extend the sample period to 2016.

We supplement the regression evidence with a propensity score matching procedure. Our analysis shows that anchor backed IPOs have significantly longer waiting period than non-anchor IPOs. This result would suggest that anchor backed IPOs should be more highly underpriced. Collectively, we can infer that anchor investors invest in hard to place offerings but reduce underpricing for such firms by reducing valuation uncertainty and pricing the IPO below the mid -point of the price band.

\section{Do Anchor Investors Earn Abnormal Returns?}

As anchor investors invest hard to place offerings, it must be that they have to be compensated for their efforts. The lock-up provision restricts them from selling shares on the listing day. Earlier papers have shown that IPOs with greater institutional investment outperform those with lower investment. This is consistent with Benveniste and Spindt (1989) who argue that underwriters prefer to allot shares in hot IPOs to institutional investors in exchange for valuable information. Aggarwal et al. (2002) provide evidence that this is indeed the case. In traditional book building, investors submit their demand before the issue price is set. Information revealed by informed investors is used in setting the issue price. At the offer price institutional investors may not necessarily realize abnormal returns. In our context anchor investors reveal the price before the book is kept open for other investors.

Profits are determined by the allocation decision of underwriters and they may reward anchor investors by allocating shares in underpriced issues. Since anchor investors face a 30-day

\footnotetext{
${ }^{22}$ In an unreported regression, we replaced the anchor dummy with reputed anchor dummy to examine whether IPOs backed by reputed anchor investors have lower waiting period. The results do not change.
} 
lock up, first day returns (traditional definition of underpricing) are less relevant to them. We calculate the hypothetical returns to anchor investors if they were to sell upon lock-up expiration ${ }^{23}$. Returns are calculated as the percentage difference between the price at which anchor investors were allotted shares and the price that prevailed on the lock-up expiration day. In order to calculate returns we hand-collect allotment dates from company websites and expiration day stock prices from the Bombay Stock Exchange website. We calculate market adjusted returns by subtracting Nifty index returns for the same period.

We find that a large fraction $(61 \%)$ of anchor-backed IPOs generate negative returns. Next we estimate returns to two sub-samples consisting of reputed and less-reputed anchor-backed IPOs. Reputed anchor backed IPOs generate better returns than the overall sample. A median IPO has a raw return of $4.03 \%$ and a market adjusted return of $2.12 \%$. Those backed by less reputed anchor investors have inferior performance. A median IPO has a raw return of $-61.67 \%$ and a market adjusted return of $-65.99 \%$. Cornelli and Goldreich (2001) find that frequent investors do not capture better profits than infrequent investors. We find the opposite.

\section{Do Anchor Backed IPOs have Superior Long-Term Performance?}

While IPOs backed by reputed anchor investors have high returns up to lock-up expiration and those backed by less reputed anchor investors are less underpriced, it is unclear whether these returns mirror the actual long-term returns to other investors. Boehmer, Boehmerand Fishe (2006) show that institutional investors obtain more allocations in IPOs with better long-term performance. Since anchor investors do not sell on the listing date or on the expiration date, we would expect these IPOs to provide adequate risk-adjusted returns in the long run. We investigate whether the performance of anchor-backed IPOs differ from that of other IPOs.

\footnotetext{
${ }^{23}$ These are hypothetical because anchor investors may hold on to the stock for the long term.
} 


\section{E.1. Four Factor Regressions}

The efficient markets hypothesis would suggest that the risk-adjusted post-IPO long-run performance should not be predictable. However, who owns shares may have the ability to predict long-term risk-adjusted performance (Field and Lowry, 2009). In order to analyze whether anchorbacked IPOs display abnormal returns, we run factor models on monthly returns derived from portfolios comprising of anchor-backed and non-anchor IPOs. We form equally weighted portfolios of anchor-backed and non-anchor backed IPOs. We collect market data from the Center for Monitoring Indian Economy's Prowess database at monthly frequency at the end of each month. Fama French (1993) regressions require constructing three risk factors viz. MRKT, SMB, and HML. Carhart's (1997) model incorporates an additional momentum factor, WML. We run regressions based on both three factor and four factor models respectively. MRKT represents market return in excess of risk free rate and is estimated as the return on S\&P CNX Nifty Index minus the risk-free rate, proxied by the yield on 91-day Treasury bill. SMB is calculated at the end of each month as the average of returns on three small-stock portfolios (based on market capitalization) minus the returns on three big-stock portfolios. Likewise, the average of returns on two high-B/M portfolios (based on Book to Market ratio) minus the two low-B/M portfolios gives the HML. WML is measured as the average of returns on two winner stock portfolios (based on the cumulative return in the last 11 months) and two loser stock portfolios ${ }^{24}$.

Table VIII reports the regression estimates. The estimates tests the null that the intercepts (alphas) are not significantly different from zero, i.e. anchor-backed IPOs do not earn excess returns on a risk adjusted basis after controlling for systematic risk factors (MRKT, SMB, HML,

\footnotetext{
${ }^{24}$ Professor Jayanth Varma of Indian Institute of Management at Ahmedabad has a public resource for Fama-French factors. See http://www.iima.ac.in/ iffm/Indian-Fama-French-Momentum/.
} 
WML) in three and four factor model specifications respectively. Focusing on Panel C of Table VIII we see that strategies that go long on anchor backed IPOs and short on non-anchor backed IPOs fail (the coefficients turn out be statistically insignificant). By comparing the $\alpha$ values from the two sets of regressions (i.e. Anchor Backed and Non-Anchor Backed Firms) we find that after adjusting for book to market, size and systematic risk, anchor backed IPOs do not earn excess returns. Results from a four-factor regression too indicate that anchor backed IPOs fail to generate excess risk adjusted returns compared to non-anchor backed IPOs. We repeat the analysis for reputed anchor investors in Panel D. Results shows that reputed anchor-backed IPOs too fail to generate excess risk-adjusted returns.

\section{E.3.The Value of Monitoring by Anchor Investors}

It is likely that anchor-backed IPOs earn superior returns through monitoring when anchor investors invest along with certain types of investors. To ascertain if this is the case, we examine the returns earned by IPOs with varying degrees of institutional and retail shareholding. The Center for Monitoring Indian Economy's Prowess database classifies investors into seven categories: founders, banks \& insurance companies, Unit Trust of India and Mutual funds, central and state government, domestic and foreign venture capital funds, non-founder corporate bodies and nonfounder individuals. Earlier papers have shown that pension funds, mutual funds and venture capitalists are likely to participate actively in corporate governance (Guercio and Hawkins, 1999; Parrino, Siasand Starks (2003); Lerner, 1995). In the Indian context too, mutual funds, pension funds, and venture capital funds serve as monitors. For example, the Unit Trust of India (UTI), a government owned mutual fund, was seeking initiatives on corporate governance from companies in the late 90 s itself $^{25}$.

\footnotetext{
${ }^{25}$ Business Standard, March 201999.
} 
If monitoring causes superior performance we would expect the performance advantage to be the highest for firms backed by anchor investors, UTI, other mutual funds, and $\mathrm{VCs}^{26}$ are the lowest for firms with little or no investment from anchor investors, UTI and VCs ${ }^{27}$. Due to economies of scale in monitoring, institutional investors such as anchor investors may resort to active monitoring only when the level of institutional shareholding is above a threshold. We examine if there is difference in returns between portfolios of firms with the highest and lowest highest institutional shareholding (top and bottom quartiles). We collect the details of shareholding soon after the IPO from CMIE's Prowess database. The results of our analysis are reported in Panel E. The results confirm our prediction that IPOs backed by anchor and other institutional investors perform better than IPOs with little institutional investor involvement. These firms generate a positive alpha of $1.25 \%$ per month (or 15\% per annum) in both three and four factor specifications.

\section{Conclusion}

While many papers have been published on IPO activity and pricing, relatively little research has been done on share allocations in initial public offerings primarily because data availability is a challenge. We bridge this gap by studying a legal experiment in India. We find that anchor investors help underwriters to market hard-to-place offerings. The presence of reputed anchors can potentially reduce valuation uncertainty, and underpricing. IPOs backed by reputed anchor investors, on average, produce $137 \%$ returns up to the lock-up expiration date. Our paper shows that the two-stage IPO process has several features that issuers, investors and regulators would consider desirable.

\footnotetext{
${ }^{26}$ This portfolio would have low retail shareholding.

${ }^{27}$ This portfolio would have high retail shareholding.
} 


\section{References}

Aggarwal, R., N. Prabhala and M. Puri, 2002, "Institutional Allocation in Initial Public Offerings: Empirical Evidence", Journal of Finance, 57, 1421-1442.

Beatty, P.R. and J.R. Ritter, 1986, "Investment banking, reputation, and the underpricing of initial public offerings", Journal of Financial Economics, 15, 213-232.

Benveniste, L.M., W.J. Wilhelm Jr. and W.Y. Busaba, 1997, "Book-building vs. fixed price: An analysis of competing strategies for marketing IPOs", Journal Financial and Quantitative Analysis, 32, 383-403.

Benveniste, L. M. and P. Spindt, 1989, "How investment bankers determine the offer price and allocation of new issues", Journal of Financial Economics, 24, 343-361.

Binay, M., V. Gatchev and C. Pirinsky, 2007, "The Role of Underwriter-Investor relationships in the IPO Process", Journal of Financial and Quantitative Analysis, 42, 785-810.

Boehmer, B., E. Boehmer and R. Fishe, 2006, "Do institutions receive favorable allocations in IPOs with better long-run returns", Journal of Financial and Quantitative Analysis, 41, 809-828.

Bubna, A. and N. Prabhala , 2011, "IPOs with and without allocation discretion: Empirical evidence", Journal of Financial Intermediation, 20 (2011), 530-561.

Bubna, A. and N. Prabhala, 2013, "Anchor Investors in IPOs", Working Paper accessible at http://w4.stern.nyu.edu/finance/docs/WP/2014/AnchorIPOs_BubnaPrabhala.pdf.

Carhart, M. M., 1997, “On Persistence in Mutual Fund Performance”, Journal of Finance, 52, 5782.

Chemmanur, T. J. and K. Krishnan, 2012, "Heterogeneous Beliefs, IPO Valuation and the Economic Role of the underwriter in IPOs", Journal of Financial Management, 41, 769-811.

Clarke, J., A. Khurshed, A. Pande and A. Singh, 2016, "Sentiment Traders and IPO Initial returns: The Indian Evidence", Journal of Corporate Finance, 37, 24-37.

Colaco, H. and S. Hegde, “The Waiting period and the performance of IPOs”. Undated. University of Connecticut Storrs Working Paper.

Cornelli, F. and D. Goldreich , 2001, "Book building and strategic allocation", Journal of Finance, 56, 2337-2369.

Cornelli, F. and D. Goldreich D, 2003, “Book building: How Informative is the Order Book?", Journal of Finance, 58, 1415-44. 
Degeorge, F., F. Derrien and K. Womack, 2007, “Analyst hype in IPOs: Explaining the popularity of book building", Review of Financial Studies, 20, 1021-1058.

Deb, S. and V. Marisetty, 2010, "Information Content of IPO Grading". Journal of Banking and Finance, 34, 2294-2305.

Hanley, K. W., 1993, "The underpricing of initial public offerings and the partial adjustment phenomenon", Journal of Financial Economics, 34, 231-250.

Fama, E. and K. French, 1992, "The Cross Section of Expected Stock returns", Journal of Finance, $47,427-465$.

Fama, E. and K. French, 1993, "Common risk factors in the returns on stocks and bonds", Journal of Financial Economics, 33, 3-56.

Field, L. C. and M. Lowry, 2009, "Institutional versus Individual Investment in IPOs: The importance of Firm Fundamentals", Journal of Financial and Quantitative Analysis, 44, 489-516.

Grossman, S. and O. Hart, 1980, "Takeover bids, the free-rider problem, and the theory of the Corporation”, Bell Journal of Economics, 11, 42-64.

Guercio, D. and J. Hawkins, 1999, "The Motivation and Impact of Pension Fund Activism", Journal of Financial Economics, 52, 293-340.

Jagannathan, R. and A. Sherman, 2005, "Reforming the Book building Process for IPOs", Journal of Applied Corporate Finance, 17, 67-72.

Jenkinson, T. and H. Jones, 2004, "Bids and allocations in European IPO book building", Journal of Finance, 59, 2309-2338.

Jenkinson, T. and H. Jones, 2009,"IPO pricing and allocation: A survey of the views of institutional investors", Review of Financial Studies, 22, 1477-1504.

Kutsuna, K, J.K. Smith and R.L. Smith, 2004, "Public Information, IPO Price Formation, and Long-Run Returns: Japanese Evidence", Journal of Finance, 64, 505-546.

Lerner, J., 1995, "Venture Capitalists and the Oversight of Private Firms", Journal of Finance, 50, 301-318.

Liu, X. and J.R. Ritter, 2010, “The economic consequences of IPO spinning”, Review of Financial Studies, 23, 2024-2059.

Loughran, T. and J.R. Ritter, 2002, "Why Don't Issuers Get Upset About Leaving Money on the Table in IPOs?", Review of Financial Studies, 15, 413-443. 
Lowry, M., M.S. Officer and G.W. Schwert, 2010, “The variability of IPO Initial Returns", Journal of Finance, 65, 425-465.

Megginson, W. and K. Weiss K, 1991, "Venture capitalist certification in IPOs", Journal of Finance, 46, 879-903.

Mello, A. and J. Parsons, 1998, "Going public and the ownership structure of the firm", Journal of Financial Economics, 49, 79-109.

Michaely, R. and W.H. Shaw, "The pricing of initial public offerings: Tests of adverse selection and signalling theories", Review of Financial Studies, 7, 279-319.

Parrino, R., R. Sias and L. Starks, 2003, "Voting with their Feet: Institutional Ownership Changes around Forced CEO Turnover", Journal of Financial Economics, 68, 3-46.

Ritter, J. and I. Welch I., 2002, “A review of IPO activity, pricing, and allocations”, Journal of Finance, 57, 1795-1828.

Ritter, J. and D. Zhang, 2007, "Affiliated mutual funds and the allocation of initial public offerings", Journal of Financial Economics, 86, 337-368.

Rock, K., 1986, “Why are new issues underpriced?”, Journal of Financial Economics, 15, 187212.

Shleifer, A. and R. Vishny, 1986, "Large shareholders and corporate control”, Journal of Political Economy, 94, 461-488.

Subrahmanyam, A. and S. Titman, "The going public decision and the development of financial markets", Journal of Finance, 54, 1045-1082.

Welch, I., 1992, "Sequential Sales, Learning and Cascades”, Journal of Finance, 47, 695-732. 
Table I: Descriptive Statistics

Panel A: Intertemporal Distribution of IPOs

\begin{tabular}{|c|c|c|c|}
\hline Year & No. of IPOs & Year & No. of IPOs \\
\hline 2007 & 103 & 2014 & 5 \\
\hline 2008 & 37 & 2015 & 21 \\
\hline 2009 & 22 & 2016 & 26 \\
\hline 2010 & 68 & & \\
\hline 2011 & 38 & & \\
\hline 2012 & 11 & & \\
\hline 2013 & 3 & & \\
\hline
\end{tabular}

Panel B: Anchor Investor Descriptive Statistics

Mean Median

Total No. of Anchor Investors

\section{Domestic \\ Foreign}

Allocation to Anchor Investors (Rs in hundred thousand)

$\%$ of issue allotted to anchor investors

Total allocation to QIBs (Rs in hundred thousands)

$\%$ of issue allotted to Qualified Institutional Buyers

No. of anchor Investors per IPO

$\begin{array}{ll}148 & \\ 167 & \\ & \\ 10,857.74 & 10,857.74 \\ 16.24 & 15.91 \\ 37,019.25 & 22,689.00 \\ 29.59 & 30.00 \\ 11 & 8\end{array}$


Panel C: Firm and Offer Characteristics

\begin{tabular}{|c|c|c|c|c|c|c|}
\hline & \multicolumn{2}{|l|}{$\begin{array}{r}\text { Anchor IPOs } \\
\mathrm{N}=52\end{array}$} & \multicolumn{2}{|c|}{$\begin{array}{l}\text { Non-Anchor IPOs } \\
\qquad \mathrm{N}=230\end{array}$} & \multicolumn{2}{|c|}{$\begin{array}{l}\text { Anchor-Non-Anchor } \\
\text { IPOs }\end{array}$} \\
\hline & Mean & Median & Mean & Median & $\mathrm{t}$ & Wilcoxon \\
\hline Firm Age & 15.33 & 12.50 & 15 & 12 & 0.105 & 0.000 \\
\hline Sales Rs m & 6511.50 & 3130.80 & 8507.49 & 1593.40 & -0.356 & 0.464 \\
\hline Total Assets & $29,541.13$ & $12,339.70$ & $52,811.62$ & 2494.95 & -0.853 & 1.457 \\
\hline Cash/Current Liabilities & 0.74 & 0.30 & 1.97 & 0.45 & -1.55 & $-1.739 *$ \\
\hline Debt/Equity & 0.92 & 0.30 & 0.63 & 0.41 & $1.73^{*}$ & -0.148 \\
\hline ROA \% & 7.4 & 7.97 & 76.10 & 5.67 & -0.560 & 0.171 \\
\hline RONW\% & 20.4 & 23.46 & 25.50 & 21.83 & -1.50 & 0.543 \\
\hline Operating cash flow per share Rs & 0.01 & -0.39 & 639.68 & 4.53 & -0.704 & -0.793 \\
\hline Issue PE/Industry PE & 1.18 & 0.70 & 2.99 & 0.76 & -0.505 & -1.215 \\
\hline Depreciation/Sales \% & 5.34 & 0.03 & 0.066 & 0.021 & $2.28 * *$ & $1.772 *$ \\
\hline Sales/Total Assets & 0.6 & 0.4 & 0.669 & 0.635 & -0.564 & -0.856 \\
\hline Net Proceeds Rs m & $702,453.39$ & $167,500.00$ & $546,534.75$ & $102,600.00$ & 0.629 & 1.22 \\
\hline Offer price Rs & 190 & 110 & 200 & 136 & -0.304 & -0.277 \\
\hline IPO Duration (days) & 148 & 135 & 214 & 170 & $2.47 * * *$ & -1.24 \\
\hline Trading Volume-Bombay Stock Ex. & $52,441,868.27$ & $20,824,993.50$ & $29,398,070.45$ & $14,772,189.00$ & 1.48 & 0.947 \\
\hline Trading Volume-National Stock Ex. & $56,540,810.13$ & $29,480,096.50$ & $37,521,813.18$ & $19,748,012.00$ & $1.66^{*}$ & 0.616 \\
\hline Institutional Subscription (times) & 13.56 & 1.54 & 21.85 & 3.01 & -1.49 & -0.092 \\
\hline Retail Subscription (times) & 5.08 & 2.63 & 9.26 & 3.53 & $-1.88^{*}$ & -1.012 \\
\hline Non Institutional Subscription (times) & 28.21 & 4.76 & 26.09 & 4.16 & 0.278 & -0.216 \\
\hline Underpricing- Bombay Stock Ex. & 7.68 & 6.10 & 19.58 & 7.11 & $-1.60 *$ & -1.376 \\
\hline Underpricing-National Stock Ex. & 5.81 & 2.73 & 24.71 & 4.02 & -0.599 & -1.288 \\
\hline Amihud Illiquidity & 0.00001181 & 0.00000076 & 0.04144566 & 0.00000252 & 0.485 & 0.228 \\
\hline
\end{tabular}




\section{Table II: Underpricing}

This table reports the results of OLS (regressions 1 through 3) and Ordered Logit regressions (regression 4) of underpricing. The dependent variable in the first three regressions and the last regression is the first day return (underpricing) on the Bombay Stock Exchange. The dependent variable in regression 4 is 0 if underpricing (U) is $\leq 0,1$ if $0<\mathrm{U}<20 \%$, 2 if $20<\mathrm{U}<40 \%$, and 3 if $\mathrm{U}>40 \%$. In regression 5 we consider IPOs till March 2016. The independent variables include an anchor dummy that takes the value of 1 if the IPO is backed by anchor investors (else zero), a reputed anchor dummy that takes the value of 1 if the IPO is backed by reputed anchor investors (else zero), the percentage of shares allotted, the percentage difference between the actual offer price and the mid-point of the filing range, natural log of issue proceeds, a lead manager reputation dummy, which is 1 if the lead manager is among the top ten in terms of markets share (else zero), the number of times the IPO is subscribed by institutional investors (QIBs), the number of times the IPO is subscribed by retail investors, standard deviation of 90-day S\&P CNX Nifty index returns prior to the filing date, 90-day average return of S\&P CNX Nifty index prior to filing date, the natural log of firm age plus 1 , and VC backed, a dummy that takes on the value of 1 if the issue is backed by venture capitalists (else zero). The $\mathrm{t}$ and Wald statistics are in parenthesis for OLS and ordered Logit regressions. The superscripts ***,**, and $*$ denote significance at the $1 \%, 5 \%$ and $10 \%$ respectively.

\begin{tabular}{lll} 
& $(1)$ & \\
\hline Anchor Dummy & $-0.93 * * *$ & \\
& $(-13.78)$ & \\
Reputed Anchor Dummy & & 0.04 \\
& & $(0.50)$
\end{tabular}

Percent of shares allotted

to anchor investors

(3)

(4) 5)

\begin{tabular}{|c|c|c|c|c|c|}
\hline Update & $\begin{array}{l}-0.04 \\
(-0.95)\end{array}$ & $\begin{array}{l}-0.12 * \\
(-1.87)\end{array}$ & $\begin{array}{l}-0.06 \\
(-1.16)\end{array}$ & $\begin{array}{l}238.44 * * * \\
(121.19)\end{array}$ & $\begin{array}{l}-0.81 \\
(0.74)\end{array}$ \\
\hline ln (Proceeds) & $\begin{array}{l}0.07 \\
(1.48)\end{array}$ & $\begin{array}{l}0.18 * * \\
(2.53)\end{array}$ & $\begin{array}{l}0.08 \\
(1.53)\end{array}$ & $\begin{array}{l}0.25 * * \\
(4.33)\end{array}$ & $\begin{array}{l}-5.21 * \\
(3.11)\end{array}$ \\
\hline LM Reputation & $\begin{array}{l}-0.04 \\
(-0.86)\end{array}$ & $\begin{array}{l}-0.04 \\
(-0.53)\end{array}$ & $\begin{array}{l}-0.03 \\
(-0.61)\end{array}$ & $\begin{array}{l}-0.63 \\
(3.39)\end{array}$ & $\begin{array}{l}2.24 \\
(6.46)\end{array}$ \\
\hline
\end{tabular}




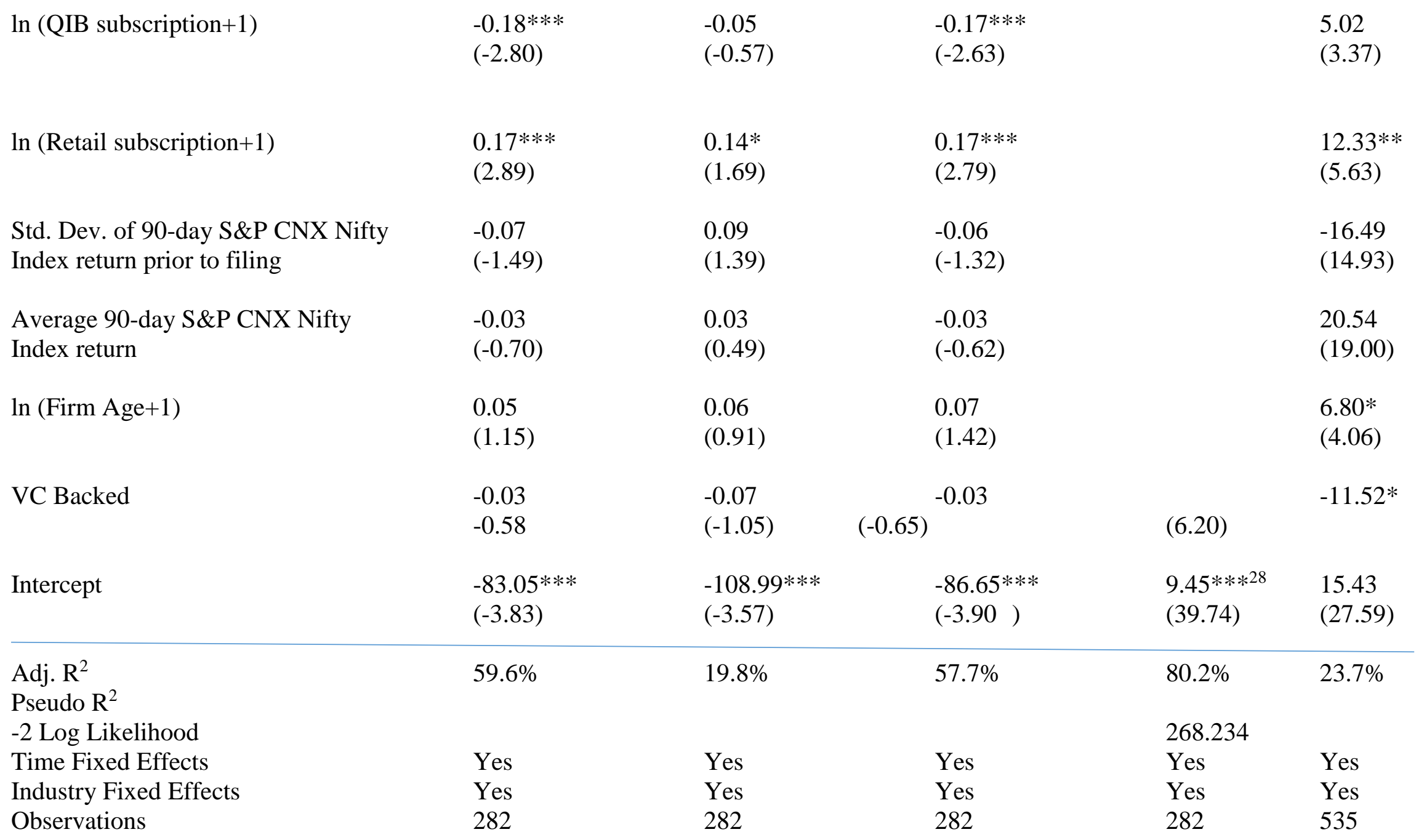

${ }^{28}$ Corresponds to an underpricing of more than $20 \%$ 


\section{Table III: Propensity Score Matching}

In this table, we compare the underpricing of anchor-backed and non-anchor IPOs using a nearest neighbor propensity matching procedure. The propensity score is estimated within a year-size category during 2009-2013 using controls (such as proceeds, firm age, firm size (total assets), VC backing dummy, subscription by institutional and retail investors, standard deviation of index returns prior to filing and average 90-day index returns prior to filing) in a logit regression analysis. The t statistics are in parenthesis. The asterisk superscript $* * *$ indicates statistical significance at the $1 \%$ level.

Mean $\% \quad$ Difference $\%$

(Anchor minus Non-

Anchor)

$\begin{array}{lll}\text { Underpricing \% (Anchor-backed) } & 7.53 & -62.26 * * * \\ & & (-3.39) \\ \text { Underpricing \% (Non-Anchor) } & 69.79\end{array}$

Mean $\% \quad$ Difference \%

(Anchor-Non-Anchor)

\begin{tabular}{lll}
\hline Absolute Underpricing (Anchor-backed) & 15.18 & $\begin{array}{l}-55.19 * * * \\
(-3.12)\end{array}$ \\
& & \\
\hline
\end{tabular}




\section{Table IV: Difference in Difference Estimation}

This table reports the difference in underpricing between anchor backed and non-anchor IPOs using the difference-in-difference estimation procedure. The regression equation is: $U P=b_{0}+b_{1}$ Date dummy $+b_{2}$ Anchor Dummy $+b_{3}$ DID. The parameters are Date Dummy, which is a Dummy variable for IPO launched before/after 2009; an Anchor Dummy variable and DID, which is the product of Date Dummy and Anchor dummy. The DiD coefficient (-50.856) in Panel D is significant at the $1 \%$ level. The asterisk superscript $* * *$ represents significance at the $1 \%$ level.

\section{Panel A: Notation followed in DiD Analysis}

\begin{tabular}{|l|l|l|l|}
\hline & Pre-AI period & Post-AI period & Overall \\
\hline AI-backed IPOs & UP11 & UP12 & UPr1 \\
\hline $\begin{array}{l}\text { Non-AI-backed } \\
\text { IPOs (NAI) }\end{array}$ & UP21 & UP22 & UPr2 \\
\hline Overall & UPc1 & UPc2 & UP \\
\hline
\end{tabular}

\section{Panel B: Underpricing of Anchor and Non-Anchor IPOs}

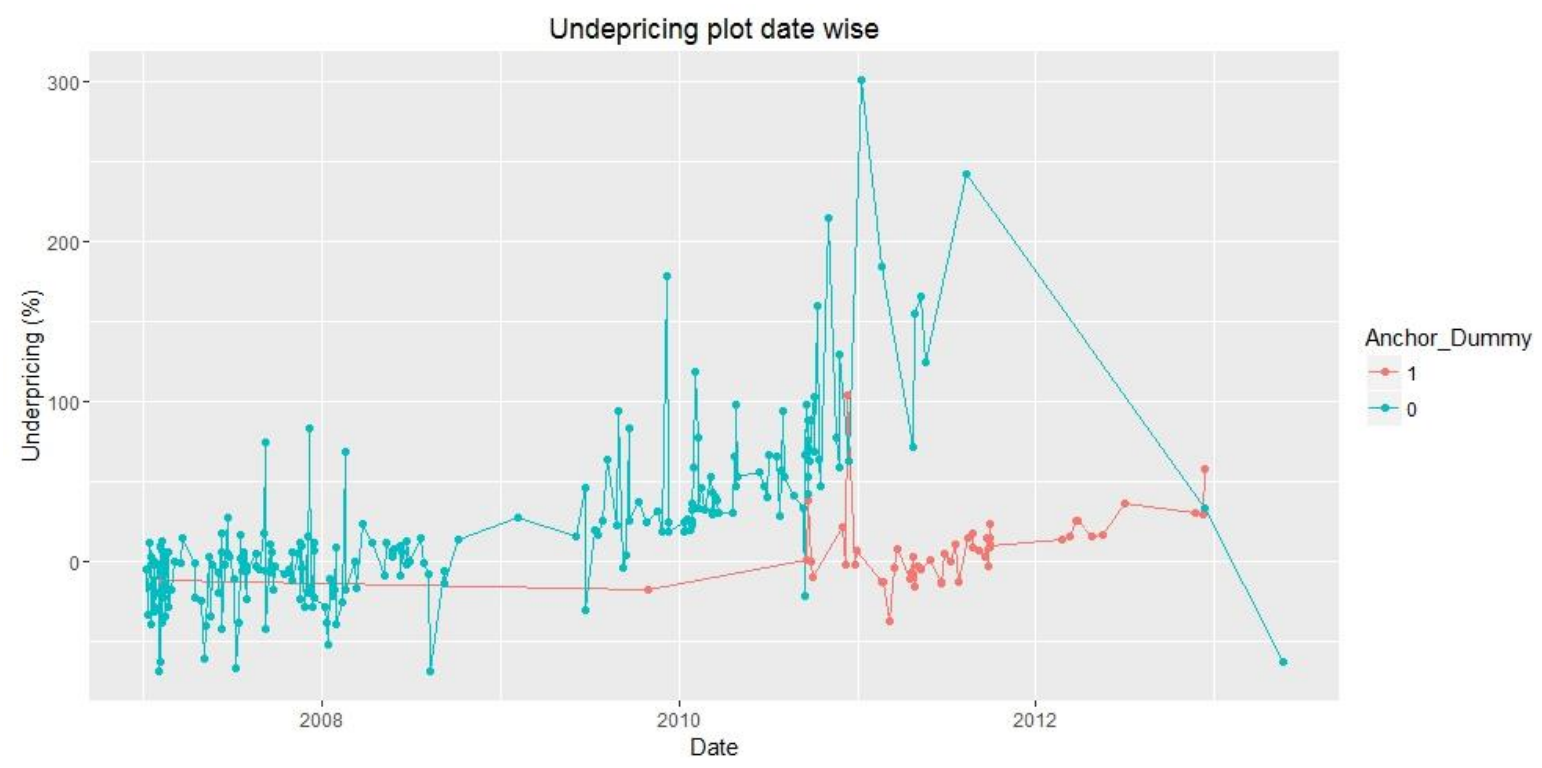

Panel C: Difference in underpricing under alternate PSM procedures (in \%)

\begin{tabular}{|l|c|c|c|c|}
\hline & $\begin{array}{c}\text { UP for } \\
\text { Anchor }\end{array}$ & $\begin{array}{c}\text { UP for Non } \\
\text { Anchor }\end{array}$ & Difference & Overall UP \\
\hline Before Matching & 7.68 & -6.03 & -13.71 & -1.92 \\
\hline $\begin{array}{l}\text { Nearest Neighbor without } \\
\text { Replacement }\end{array}$ & 7.68 & -5.63 & -13.31 & 1.02 \\
\hline NN With Replacement & 7.68 & -2.01 & -9.68 & 2.84 \\
\hline $\begin{array}{l}\text { NN with Caliper =0.21 } \\
\text { with Replacement }\end{array}$ & 7.68 & -10.60 & -18.28 & 0.11 \\
\hline $\begin{array}{l}\text { NN with Mahalanobis and } \\
\text { Replacement }\end{array}$ & 7.68 & -9.98 & -17.66 & -1.15 \\
\hline
\end{tabular}


Panel D: Double difference in underpricing (in \%)

Before Matching

\begin{tabular}{|l|c|c|c|c|}
\hline & $\begin{array}{c}\text { Post - AI period } \\
(1)\end{array}$ & Pre-AI Period (2) & Overall & $\begin{array}{c}\text { Difference (1) - } \\
(2)\end{array}$ \\
\hline AI- backed IPO & 7.68 & & 7.68 & \\
\hline $\begin{array}{l}\text { Non - AI backed } \\
\text { IPO }\end{array}$ & 61.62 & -6.03 & 19.52 & 67.65 \\
\hline Overall & 41.18 & -6.03 & 18.51 & \\
\hline
\end{tabular}

After Matching

\begin{tabular}{|l|c|c|c|c|}
\hline & $\begin{array}{l}\text { Post - AI period } \\
(1)\end{array}$ & $\begin{array}{c}\text { Pre-AI Period } \\
(2)\end{array}$ & Overall & $\begin{array}{c}\text { Difference (1) - } \\
(2)\end{array}$ \\
\hline AI- backed IPO (3) & 7.68 & -9.98 & -1.15 & 17.66 \\
\hline $\begin{array}{l}\text { Non - AI backed IPO } \\
(4)\end{array}$ & 61.62 & -6.89 & 27.36 & 68.51 \\
\hline Overall & 41.18 & -6.62 & 18.51 & \\
\hline Difference (3)- (4) & -53.94 & -3.09 & & $-50.85^{* * *}$ \\
\hline
\end{tabular}




\section{Table V: Determinants of Anchor Investors' Participation in IPOs}

This Table reports the results of Logit (Models 1 and 2) and OLS regressions (Model 3). The dependent variable in Model 1 is a dummy that takes the value of 1 if the IPO is backed by Anchor Investors. The dependent variable in Model 2 is a dummy that takes the value of 1 if the IPO is backed by reputed anchor investors. The dependent variable in Model 3 is the percentage of shares allotted to anchor investors. The independent variables are the natural $\log$ of issue proceeds, natural log of firm age plus 1 , natural log of total assets, cash flow dummy that takes the value of 1 if the company has negative cash flows, group affiliation, which is a dummy that takes the value of 1 if the issuing company belongs to a business group, LM reputation, a dummy that takes the value of 1 if the IPO is lead managed by one of the top ten lead managers in terms of market share, relative valuation is the ratio of Price-Earnings multiple of the IPO implied by the mid-point of the filing range and the prevailing industry priceearnings multiple, VC backed, a dummy that takes the value of 1 if the company has received investment from venture capitalists prior to the IPO, return on assets, sales/total assets, debt/equity, and cash/current liabilities. The asterisk superscripts ${ }^{*},{ }^{* *}$, and ${ }^{* * *}$ represent the $10 \%, 5 \%$, and $1 \%$ two-tailed significance level, respectively. The Wald and $t$ statistics are in the parentheses for Logit and OLS regressions.

Logit Regressions $\quad$ OLS Regression

Dependent Variable

\begin{tabular}{ll}
\hline Anchor & Reputed $\quad \%$ shares allotted \\
Dummy & Anchor \\
& Dummy
\end{tabular}

\begin{tabular}{|c|c|c|c|}
\hline ln (Proceeds) & $\begin{array}{l}-0.584 * * \\
(-4.922)\end{array}$ & $\begin{array}{l}0.434 \\
(2.495)\end{array}$ & $\begin{array}{l}-0.205 * * * \\
(-2.886)\end{array}$ \\
\hline ln (Firm Age+1) & $\begin{array}{l}0.113 \\
(0.036)\end{array}$ & $\begin{array}{l}0.772 \\
(1.595)\end{array}$ & $\begin{array}{l}0.068 \\
(0.894)\end{array}$ \\
\hline $\ln$ (Assets) & $\begin{array}{l}-0.388 \\
(-2.181)\end{array}$ & $\begin{array}{l}-0.283 \\
(-1.087)\end{array}$ & $\begin{array}{l}-0.218 * * \\
(-2.326)\end{array}$ \\
\hline Cash Flow Dummy & $\begin{array}{l}-0.440 \\
(-0.519)\end{array}$ & $\begin{array}{l}-1.178 \\
(-1.846)\end{array}$ & $\begin{array}{l}-0.091 \\
(-1.304)\end{array}$ \\
\hline Group Affiliation & $\begin{array}{l}1.203 \\
(2.339)\end{array}$ & $\begin{array}{l}-0.535 \\
(-0.259)\end{array}$ & $\begin{array}{l}0.125 \\
(1.598)\end{array}$ \\
\hline LM Reputation & $\begin{array}{l}0.092 \\
(0.022)\end{array}$ & $\begin{array}{l}0.926 \\
(1.405)\end{array}$ & $\begin{array}{l}0.033 \\
(0.467)\end{array}$ \\
\hline Relative Valuation & $\begin{array}{l}-0.012 \\
(-0.007)\end{array}$ & $\begin{array}{l}0.010 \\
(0.115)\end{array}$ & $\begin{array}{l}-0.001 \\
(-0.018)\end{array}$ \\
\hline VC Backed & $\begin{array}{l}1.649^{*} \\
(3.092)\end{array}$ & $\begin{array}{l}2.800 * * * \\
(9.690)\end{array}$ & $\begin{array}{l}0.174 * * * \\
(2.480)\end{array}$ \\
\hline $\mathrm{ROA}$ & $\begin{array}{l}-0.003 \\
(-0.015)\end{array}$ & $\begin{array}{l}-0.104 * \\
(-2.818)\end{array}$ & $\begin{array}{l}-0.023 \\
(-0.297)\end{array}$ \\
\hline Sales/ Assets & $\begin{array}{l}-0.123 \\
(-0.049)\end{array}$ & $\begin{array}{l}-1.013 \\
(-1.044)\end{array}$ & $\begin{array}{l}-0.060 \\
(-0.753)\end{array}$ \\
\hline Debt/Equity & -0.228 & 0.378 & 0.039 \\
\hline
\end{tabular}




\begin{tabular}{|c|c|c|c|}
\hline & $(-0.175)$ & $(0.876)$ & $(0.510)$ \\
\hline Cash/Current Liabilities & $\begin{array}{l}0.051 \\
(0.454)\end{array}$ & $\begin{array}{l}0.111 \\
(2.261)\end{array}$ & $\begin{array}{l}0.026 \\
(0.375)\end{array}$ \\
\hline Intercept & $\begin{array}{l}10.322 * * * \\
(6.777)\end{array}$ & $\begin{array}{l}-3.330 \\
(-0.923)\end{array}$ & $\begin{array}{l}22.016^{*} \\
(5.085)\end{array}$ \\
\hline Pseudo $R^{2}$ (Adj. $R^{2}$ for OLS) & $36.5 \%$ & $25.5 \%$ & $28.2 \%$ \\
\hline-2 Log likelihood & 75.883 & 52.80 & \\
\hline $\begin{array}{l}\text { Observations correctly } \\
\text { Classified }\end{array}$ & $89.8 \%$ & $94.3 \%$ & \\
\hline Time Fixed Effects & Yes & Yes & Yes \\
\hline Industry Fixed Effects & Yes & Yes & Yes \\
\hline P Value & 0.00 & 0.00 & 0.00 \\
\hline No. of observations & 282 & 282 & 282 \\
\hline
\end{tabular}




\section{Table VI: Anchor Investors and Valuation Uncertainty}

This Table reports the results of OLS regressions. The dependent variable in all regressions is the percentage width of the price band. The independent variables are an anchor dummy that takes the value of 1 if the IPO is backed by anchor investors, a reputed anchor dummy that takes the value of 1 if the IPO is backed by reputed anchor investors, natural log of issue proceeds, LM reputation, a dummy that takes the value of 1 if the IPO is lead managed by one of the top ten lead managers in terms of market share, standard deviation of 90-day S\&P CNX Nifty index returns prior to the red herring prospectus filing date, natural log of firm age plus 1 , group affiliation dummy which is set at 1 if the IPO firm belongs to a business group, VC backed, a dummy that takes on the value of 1 if the issue is backed by venture capitalists, and natural log of total assets. The $t$ statistics are in parentheses. The asterisk superscripts ${ }^{*},{ }^{* *}$, and ${ }^{* * *}$ represent the $10 \%, 5 \%$, and $1 \%$ two-tailed significance level, respectively.

\begin{tabular}{lll}
\hline Anchor Dummy & $-0.257^{* * *}$ & 0.052 \\
& $(-3.575)$ & $(0.540)$
\end{tabular}

Reputed Anchor Dummy

$\begin{array}{ll}-0.126^{*} & -0.004 \\ (-1.734) & (-0.051)\end{array}$

$\ln$ (proceeds)

$-0.084$

$(-1.243)$

$-0.020$

$-0.047$

$-0.029$

$-0.058$

$(-0.300)$

$(-0.685)$

$(-0.450)$

LM Reputation

$(-0.858)$

$-0.073$

$-0.061$

$-0.072$

Std. deviation of 90-day

$-0.051$

$(-1.120)$

$(-0.880)$

$(-1.103)$

Nifty Index returns

$(-0.755)$

$-0.031$

$-0.003$

$-0.038$

Ln (Firm Age + 1)

$-0.115^{*}$

$(-0.478)$

$(-0.038)$

$(-0.597)$
Ln (Firm Age +1$)$
(-1.630)

$-0.124^{*}$

$-0.098$

$-0.128 *$

Group Affiliation Dummy

0.102

(-1.848)

(-1.355)

(-1.890)

VC Backed?

(1.410)

$0.115^{*}$

0.090

$0.118^{*}$

(1.672)

(1.219)

(1.698)

0.065

0.039

0.090

(1.272)

0.043

(0.969)

(0.611)

(0.643) 


\begin{tabular}{lllll}
$\ln$ (Total Assets) & $\begin{array}{l}0.168^{* *} \\
(2.21)\end{array}$ & $\begin{array}{l}0.132^{* *} \\
(1.815)\end{array}$ & $\begin{array}{l}0.118 \\
(1.552)\end{array}$ & $\begin{array}{l}0.141^{* *} \\
(1.990)\end{array}$ \\
Intercept & $\begin{array}{l}0.131^{* * *} \\
(4.219)\end{array}$ & $\begin{array}{l}0.149^{* * *} \\
(5.008)\end{array}$ & $\begin{array}{l}0.115^{* * *} \\
(3.681)\end{array}$ & $\begin{array}{l}0.150^{* * * *} \\
(5.020)\end{array}$ \\
\hline Adj. $\mathrm{R}^{2}$ & $5.7 \%$ & $14.1 \%$ & $1.4 \%$ & $13.8 \%$ \\
Time Fixed Effects & No & Yes & No & Yes \\
Industry Fixed Effects & No & Yes & No & Yes \\
Observations & 282 & 282 & 282 & 282
\end{tabular}




\section{Table VII: Anchor Investors' Impact on Duration and Pricing of IPOs}

This Table reports the results of Logit and Negative Binomial regressions respectively. The dependent variable in Model 1 is a dummy that takes the value of 1 if the IPO is priced at the upper end of the price band (zero otherwise). The dependent variable in Model 2 is the time elapsed in days between prospectus filing date and the offer date (waiting period). The independent variables are an anchor dummy that takes the value of 1 if the IPO is backed by anchor investors, natural log of issue proceeds, LM reputation, a dummy that takes the value of 1 if the IPO is lead managed by one of the top ten lead managers in terms of market share and percent change in S\&P CNX Nifty index from filing date to offer date. The Wald statistics are in parentheses for Logit and Negative Binomial regressions. The asterisk superscripts ${ }^{*},{ }^{* *}$, and ${ }^{* * *}$ represent the $10 \%, 5 \%$, and $1 \%$ two-tailed significance level, respectively.

(1)

Anchor Dummy

$\ln$ (proceeds)

LM Reputation

Change in Nifty index
0.020

$(0.999)$

$22.843 * * *$

(18.689)

$-10.207 * * *$

(13.808)

$-0.021$

$-0.876$

(1.339)

(2)

$0.259^{*}$

0.045

(0.227)

$0.149 * * *$

(15.663)

$-0.021$

$(0.389)$

$4.862 * * *$

(180.885)
$56.2 \%$

$97.3 \%$

51.314

-2 Log likelihood

Likelihood Ratio Chi-Square

Log Likelihood

Pearson Chi-Square

$P$ Value

Time Fixed Effects

Industry Fixed Effects

Observations

Pseudo $\mathrm{R}^{2}$

$\begin{array}{ll} & 27.995 \\ & -1658.454 \\ & 139.907 \\ 0.00 & 0.00 \\ \text { Yes } & \text { Yes } \\ \text { Yes } & \text { Yes } \\ 282 & 282\end{array}$




\section{Table VIII: Test of Portfolio Return Performance: Anchor and Non-anchor backed IPOs}

This table reports the results of Fama-French and four factor regressions. The sample period consists of 94 monthly observations from March 2006 to November 2013.

Figures in the parenthesis and curly brackets represent the $\mathrm{t}$-statistics and p-values respectively. The superscript asterisks $*, * *, * * *$ show the statistical significance at $10 \%$, $5 \%$ and $1 \%$ respectively is the risk-free rate.

\begin{tabular}{|c|c|c|c|c|c|c|c|c|}
\hline \multirow[t]{2}{*}{ Portfolios } & \multirow{2}{*}{$\alpha$} & \multirow{2}{*}{$\beta$ mrkt } & \multirow{2}{*}{$\beta_{\mathrm{smb}}$} & \multirow{2}{*}{ Bhml } & \multirow{2}{*}{$\beta_{w m l}$} & \multirow{2}{*}{$\begin{array}{l}\text { R- } \\
\text { squared }\end{array}$} & \multicolumn{2}{|c|}{ Prob> F } \\
\hline & & & & & & & $\begin{array}{l}\text { F } \\
(\mathbf{3}, \mathbf{5 3})\end{array}$ & $\begin{array}{l}\mathbf{F} \\
(4,52)\end{array}$ \\
\hline \multicolumn{9}{|c|}{ Panel (A) Anchor backed IPOS } \\
\hline \multirow[t]{2}{*}{ Anchor } & $\begin{array}{c}0.00 \\
(0.44)\end{array}$ & $\begin{array}{c}0.91 * * * \\
(6.30)\end{array}$ & $\begin{array}{c}-0.05 \\
(-0.21)\end{array}$ & $\begin{array}{c}0.26 \\
(1.15)\end{array}$ & & 0.5564 & $\begin{array}{c}22.16 \\
\{0.00\}\end{array}$ & \\
\hline & $\begin{array}{l}0.02 * * \\
(1.65)\end{array}$ & $\begin{array}{c}0.85^{* * * *} \\
(6.09)\end{array}$ & $\begin{array}{c}0.05 \\
(0.20)\end{array}$ & $\begin{array}{c}0.35 \\
(1.53)\end{array}$ & $\begin{array}{c}-0.16 \\
(-1.70)\end{array}$ & 0.5798 & & $\begin{array}{c}17.94 \\
\{0.00\}\end{array}$ \\
\hline \multirow[t]{2}{*}{ Anchor-Rf } & $\begin{array}{c}0.03 * * * \\
(3.31)\end{array}$ & $\begin{array}{c}0.89 * * * \\
(6.30)\end{array}$ & $\begin{array}{c}-0.08 \\
(-0.33)\end{array}$ & $\begin{array}{c}0.25 \\
(1.06)\end{array}$ & & 0.5415 & $\begin{array}{l}20.87 \\
\{0.00\}\end{array}$ & \\
\hline & $\begin{array}{c}0.05^{* * * *} \\
(3.31) \\
\end{array}$ & $\begin{array}{c}0.84 * * * \\
(5.87)\end{array}$ & $\begin{array}{c}0.02 \\
(0.07) \\
\end{array}$ & $\begin{array}{c}0.34 \\
(1.43)\end{array}$ & $\begin{array}{c}0.16 \\
(-1.68) \\
\end{array}$ & 0.5650 & & $\begin{array}{r}16.89 \\
\{0.00\} \\
\end{array}$ \\
\hline \multicolumn{9}{|c|}{ Panel (B) Non-Anchor backed IPOs } \\
\hline \multirow[t]{2}{*}{ NonAnchor } & $\begin{array}{c}0.03 * * * \\
(3.38) \\
\end{array}$ & $\begin{array}{l}1.29 * * * \\
(12.79)\end{array}$ & $\begin{array}{c}-0.08 \\
(-1.06) \\
\end{array}$ & $\begin{array}{c}-0.12 \\
(-1.32) \\
\end{array}$ & & 0.6421 & $\begin{array}{l}58.01 \\
\{0.00\}\end{array}$ & \\
\hline & $\begin{array}{c}0.01 \\
(0.73) \\
\end{array}$ & $\begin{array}{l}1.28 * * * \\
(13.12)\end{array}$ & $\begin{array}{c}-0.09 \\
(-0.49) \\
\end{array}$ & $\begin{array}{c}0.11 \\
(0.52)\end{array}$ & $\begin{array}{c}0.21 \\
(5.66) \\
\end{array}$ & 0.7607 & & $\begin{array}{r}65.17 \\
\{0.00\} \\
\end{array}$ \\
\hline \multirow[t]{2}{*}{ NonAnchor-Rf } & $\begin{array}{c}0.00 \\
(-0.03)\end{array}$ & $\begin{array}{c}0.85^{* * * *} \\
(7.04)\end{array}$ & $\begin{array}{c}0.13 \\
(0.65)\end{array}$ & $\begin{array}{c}0.33 \\
(1.69)\end{array}$ & & 0.5962 & $\begin{array}{l}26.08 \\
\{0.00\}\end{array}$ & \\
\hline & $\begin{array}{c}0.00 \\
(-0.21)\end{array}$ & $\begin{array}{c}0.86^{* * * *} \\
(7.04)\end{array}$ & $\begin{array}{c}0.11 \\
(0.57)\end{array}$ & $\begin{array}{c}0.31 \\
(1.58)\end{array}$ & $\begin{array}{c}0.00 \\
(-0.44)\end{array}$ & 0.5966 & & $\begin{array}{c}19.23 \\
\{0.00\}\end{array}$ \\
\hline \multicolumn{9}{|c|}{ Panel (C) Long-Short Portfolio of Anchor and Non-Anchor backed IPOs } \\
\hline \multirow[t]{2}{*}{$\begin{array}{l}\text { Anchor-Non- } \\
\text { Anchor }\end{array}$} & $\begin{array}{c}0.00 \\
(0.42) \\
\end{array}$ & $\begin{array}{c}0.06 \\
(0.47)\end{array}$ & $\begin{array}{c}-0.17 \\
(-0.77)\end{array}$ & $\begin{array}{c}-0.06 \\
(-0.29)\end{array}$ & & 0.0216 & $\begin{array}{c}0.39 \\
\{0.76\}\end{array}$ & \\
\hline & $\begin{array}{c}0.02 \\
(1.86) \\
\end{array}$ & $\begin{array}{c}0.00 \\
(0.03) \\
\end{array}$ & $\begin{array}{c}-0.07 \\
(-0.29) \\
\end{array}$ & $\begin{array}{c}0.04 \\
(0.16) \\
\end{array}$ & $\begin{array}{c}-0.18 \\
(-1.97) \\
\end{array}$ & 0.0896 & & $\begin{array}{c}1.28 \\
\{0.29\} \\
\end{array}$ \\
\hline \multicolumn{9}{|c|}{ Panel (D) Long-Short Portfolio of Reputed Anchor and Non-Anchor backed IPOs } \\
\hline \multirow[t]{2}{*}{$\begin{array}{l}\text { Reputed Anchor- } \\
\text { Non-Anchor }\end{array}$} & $\begin{array}{c}0.00 \\
(0.39) \\
\end{array}$ & $\begin{array}{c}0.09 \\
(0.63)\end{array}$ & $\begin{array}{c}-0.09 \\
(-0.41)\end{array}$ & $\begin{array}{c}-0.03 \\
(-0.13)\end{array}$ & & 0.0160 & $\begin{array}{c}0.29 \\
\{0.83\}\end{array}$ & \\
\hline & $\begin{array}{c}0.02 \\
(1.84)\end{array}$ & $\begin{array}{c}0.03 \\
(0.19)\end{array}$ & $\begin{array}{c}0.02 \\
(0.07)\end{array}$ & $\begin{array}{c}0.07 \\
(0.32)\end{array}$ & $\begin{array}{c}-0.18 \\
(-1.97)\end{array}$ & 0.0846 & & $\begin{array}{c}1.20 \\
\{0.32\}\end{array}$ \\
\hline
\end{tabular}




\begin{tabular}{|c|c|c|c|c|c|c|c|c|}
\hline \multicolumn{9}{|c|}{ Panel (E) Institutional Portfolio } \\
\hline \multirow[t]{2}{*}{$\begin{array}{l}\text { Institutional- } \\
\text { Rf }\end{array}$} & $\begin{array}{c}-2.29 * * * \\
(-5.24)\end{array}$ & $\begin{array}{c}0.99 * * * \\
(18.82)\end{array}$ & $\begin{array}{c}0.54 * * \\
* \\
(5.60)\end{array}$ & $\begin{array}{c}0.50 * * \\
* \\
(3.78)\end{array}$ & & 0.8941 & 0.0000 & \\
\hline & $\begin{array}{c}-2.35 * * * \\
(-5.26)\end{array}$ & $\begin{array}{l}1.00 * * * \\
(17.04)\end{array}$ & $\begin{array}{c}0.54 * * \\
* \\
(5.50)\end{array}$ & $\begin{array}{c}0.54 * * \\
* \\
(3.78)\end{array}$ & $\begin{array}{c}0.05 \\
(0.70)\end{array}$ & 0.8948 & & 0.0000 \\
\hline \multicolumn{9}{|c|}{ Non-institutional Portfolio } \\
\hline \multirow[t]{2}{*}{$\begin{array}{l}\text { Non- } \\
\text { Institutional- } \\
\text { Rf }\end{array}$} & $\begin{array}{c}-3.54 * * * \\
(-7.64)\end{array}$ & $\begin{array}{l}1.11 * * * \\
(20.02)\end{array}$ & $\begin{array}{l}0.82 * * \\
* \\
(7.93)\end{array}$ & $\begin{array}{c}0.57 * * \\
* \\
(4.06)\end{array}$ & & 0.9079 & 0.0000 & \\
\hline & $\begin{array}{c}-3.57 * * * \\
(-7.52)\end{array}$ & $\begin{array}{l}1.12 * * * \\
(17.89)\end{array}$ & $\begin{array}{c}0.82 * * \\
* \\
(7.82) \\
\end{array}$ & $\begin{array}{c}0.60 * * \\
* \\
(3.90) \\
\end{array}$ & $\begin{array}{c}0.03 \\
(0.34)\end{array}$ & 0.9081 & & 0.0000 \\
\hline \multicolumn{9}{|c|}{ Institutional Minus Non-Institutional Portfolio } \\
\hline \multirow[t]{2}{*}{$\begin{array}{l}\text { Institutional- } \\
\text { Non- } \\
\text { Institutional }\end{array}$} & $\begin{array}{l}1.25 * * \\
(2.40)\end{array}$ & $\begin{array}{c}-0.13 * * \\
(-2.04)\end{array}$ & $\begin{array}{c}- \\
0.27 * * \\
(-2.35)\end{array}$ & $\begin{array}{c}-0.07 \\
(-0.45)\end{array}$ & & 0.1454 & 0.0113 & \\
\hline & $\begin{array}{l}1.23 * * \\
(2.28)\end{array}$ & $\begin{array}{c}-0.12 * * \\
(-1.68)\end{array}$ & $\begin{array}{c}- \\
0.28^{* *} \\
(-2.35)\end{array}$ & $\begin{array}{c}-0.05 \\
(-0.31)\end{array}$ & $\begin{array}{c}0.03 \\
(0.29)\end{array}$ & 0.1465 & & 0.0256 \\
\hline
\end{tabular}




\section{Appendix A: Construction of Variables}

\begin{tabular}{|c|c|}
\hline Variable & Data Source \\
\hline Firm Financial Statements & CMIE PROWESS database \\
\hline Anchor investors' market share & Prime IPO database \\
\hline $\begin{array}{l}\text { Percent shares allotted to anchor } \\
\text { Investors }\end{array}$ & Prime IPO database \\
\hline IPO Price band & Prime IPO database \\
\hline Underwriter Fees & Prime IPO database \\
\hline Business Line Recommendation & Business Line \\
\hline Stock Price & Bombay Stock Exchange \\
\hline Trading Volume & Bombay Stock Exchange, National Stock Exchange \\
\hline Nifty Index Returns & National Stock Exchange \\
\hline IPO Price/Earnings Multiple & IPO Prospectus \\
\hline Industry Price/Earnings Multiple & IPO Prospectus \\
\hline Underwriter Rankings & Thomson ONE, Prime IPO database \\
\hline Subscription & $\begin{array}{l}\text { Company Website, Prime IPO Database, } \\
\text { Chittorgarh.com }\end{array}$ \\
\hline Group affiliation & CMIE PROWESS database \\
\hline Venture Capital affiliation & CMIE PROWESS database \\
\hline Firm Age & CMIE PROWESS database \\
\hline Shareholding Pattern & CMIE PROWESS database \\
\hline 91-day Treasury bill rate & $\begin{array}{l}\text { RBI website } \\
\text { (http://www.rbi.org.in/scripts/BS_ViewBulletin.aspx) }\end{array}$ \\
\hline
\end{tabular}




\section{Appendix B: Difference-in-Difference estimation of underpricing with covariates and industry and time fixed effects}

This table reports the difference in underpricing between anchor backed and non-anchor IPOs using the differencein-difference estimation procedure. The regression equation is: $U P=b_{0}+b_{1}$ Date dummy $+b_{2}$ Anchor Dummy $+b_{3}$ DID $+b_{i}\left(X_{j}\right)$. The parameters are Date Dummy, which is a Dummy variable for IPO launched before/after 2009; an Anchor Dummy variable and DID, which is the product of Date Dummy and Anchor dummy and $\mathrm{X}_{\mathrm{i}}$ are covariates. The DiD coefficient (-80.00) is significant at the $1 \%$ level. The asterisk superscripts $* * *, * *$, and * represent significance at the $1 \%, 5 \%$ and $10 \%$ levels.

\begin{tabular}{|c|c|}
\hline Date Dummy & $\begin{array}{l}45.800 * * \\
(18.700)\end{array}$ \\
\hline Anchor & $\begin{array}{l}-0.032 \\
(6.770)\end{array}$ \\
\hline DID & $\begin{array}{l}-80.000 * * * \\
(11.000)\end{array}$ \\
\hline Age & $\begin{array}{l}-2.360 \\
(3.850)\end{array}$ \\
\hline Proceeds & $\begin{array}{l}4.590 * * \\
(1.910)\end{array}$ \\
\hline VC Backed & $\begin{array}{l}-18.000 * * \\
(7.120)\end{array}$ \\
\hline LM Reputation & $\begin{array}{l}-8.380 * \\
(4.680)\end{array}$ \\
\hline Update & $\begin{array}{l}-44.500 \\
(30.500)\end{array}$ \\
\hline $\begin{array}{l}\text { Avg 90-Day Nifty } \\
\text { Index Return }\end{array}$ & $\begin{array}{l}-1,145.000 \\
(1,255.000)\end{array}$ \\
\hline $\begin{array}{l}\text { Std. Deviation of 90-day } \\
\text { Nifty Index Returns }\end{array}$ & $\begin{array}{c}104.000 \\
(491.000)\end{array}$ \\
\hline Ln (QIB Subscription +1 ) & $\begin{array}{r}-5.290 * * \\
(2.360)\end{array}$ \\
\hline Ln (Retail Subscription +1) & $\begin{array}{l}4.750 \\
(3.080)\end{array}$ \\
\hline Constant & $\begin{array}{c}17.300 \\
(29.400)\end{array}$ \\
\hline $\begin{array}{l}\text { Observations } \\
\text { R2 } \\
\text { Adjusted R2 } \\
\text { Residual Std. Error } \\
\text { F Statistic }\end{array}$ & $\begin{array}{c}263 \\
0.511 \\
0.464 \\
100(\mathrm{df}=239) \\
* * *(\mathrm{df}=23 ; 239)\end{array}$ \\
\hline
\end{tabular}

